\title{
Instructions for Running the Analytical Code PAT (Purge Analyzer Tool) for Computation of In-Well Time of Travel of Groundwater under Pumping Conditions
}

Open-File Report 2019-1104 



\section{Instructions for Running the Analytical Code PAT (Purge Analyzer Tool) for Computation of In-Well Time of Travel of Groundwater under Pumping Conditions}

By P.T. Harte, B.J. Huffman, Tomas Perina, Herb Levine, and

Daewon Rojas-Mickelson

Prepared in cooperation with the U.S. Environmental Protection Agency

Open-File Report 2019-1104 


\title{
U.S. Department of the Interior DAVID BERNHARDT, Secretary
}

\author{
U.S. Geological Survey \\ James F. Reilly II, Director
}

\section{U.S. Geological Survey, Reston, Virginia: 2019}

For more information on the USGS - the Federal source for science about the Earth, its natural and living resources, natural hazards, and the environment—visit https://www.usgs.gov or call 1-888-ASK-USGS.

For an overview of USGS information products, including maps, imagery, and publications, visit https://store.usgs.gov.

Any use of trade, firm, or product names is for descriptive purposes only and does not imply endorsement by the U.S. Government.

Although this information product, for the most part, is in the public domain, it also may contain copyrighted materials as noted in the text. Permission to reproduce copyrighted items must be secured from the copyright owner.

Suggested citation:

Harte, P.T., Huffman, B.J., Perina, T., Levine, H., and Rojas-Mickelson, D., 2019, Instructions for running the analytical code PAT (Purge Analyzer Tool) for computation of in-well time of travel of groundwater under pumping conditions: U.S. Geological Survey Open-File Report 2019-1104, 23 p., https://doi.org/10.3133/ofr20191104.

ISSN 2331-1258 (online) 


\section{Disclaimer}

This software has been approved for release by the U.S. Geological Survey (USGS). Although the software has been subjected to rigorous review, the USGS reserves the right to update the software as needed pursuant to further analysis and review. No warranty, expressed or implied, is made by the USGS or the U.S. Government as to the functionality of the software and related material nor shall the fact of release constitute any such warranty. Furthermore, the software is released on condition that neither the USGS nor the U.S. Government shall be held liable for any damages resulting from its authorized or unauthorized use. The PAT (Purge Analyzer Tool) can be downloaded at https://code.usgs.gov/ptharte/pat.

\section{Acknowledgments}

This work was done under an interagency agreement (DW-014-9246101) with the U.S. Environmental Protection Agency (EPA) initiative on Characterization of Fractured Rock. The authors would like to thank Edward Gilbert of EPA for his oversight on this initiative. During testing of the PAT program, several remedial project managers from the EPA helped facilitate data exchange of sampling records of wells. These data proved helpful to assess hydraulic responses of pumped wells. Richard Hull and Carol Keating of EPA, Region 1, and Richard Mayer of EPA, Region 6 all helped with these data requests. Several state project managers also helped with data requests including Peter Bailey and David Herzog of the California Department of Toxic Substances Control. Michael Kulbersh of the U.S. Army Corp of Engineers, New England, served as a technical reviewer and provided important comments on this manual and the PAT program. 



\section{Contents}

Acknowledgments ….......................................................................................................................

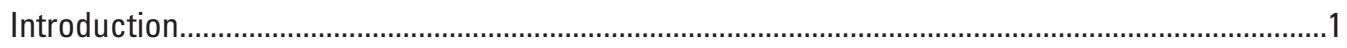

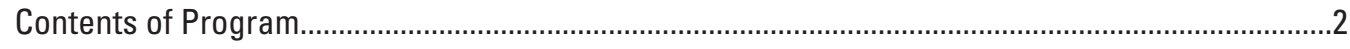

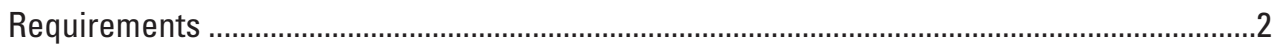

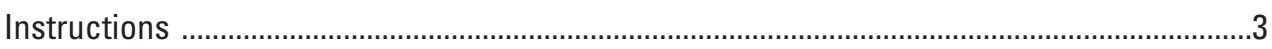

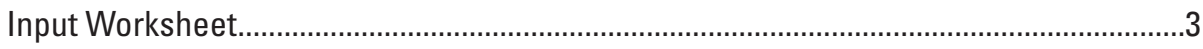

Output Worksheet

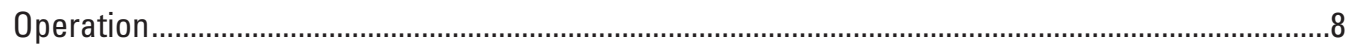

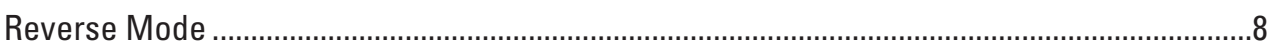

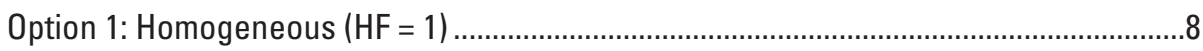

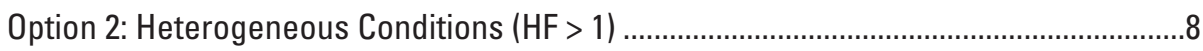

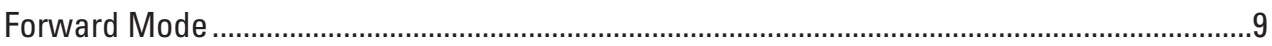

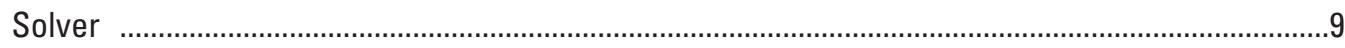

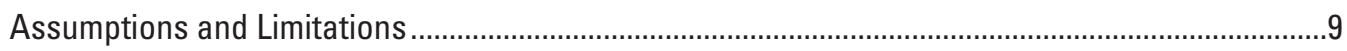

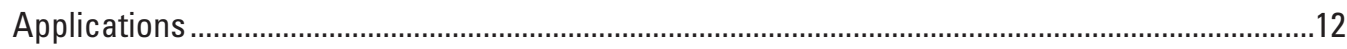

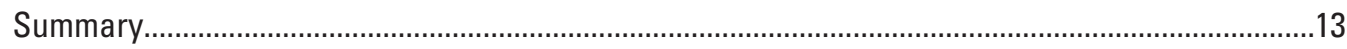

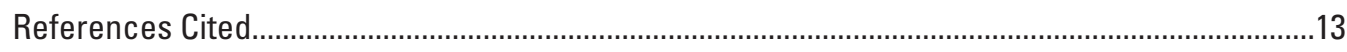

Appendix 1. Solution Examples using Purge Analyzer Tool .........................................................16

Appendix 2. Incorporation of Stratigraphic Information in Simulation ......................................18

Appendix 3. Additional Examples of Input and Output...............................................................

\section{Figures}

1. Diagram showing schematic of the allocation of flow in the well while pumping for the Purge Analyzer Tool...............................................................................................

2. Screenshot showing reproduction of user-specified input parameters (cells B4:B14) on the "Input" worksheet for the Purge Analyzer Tool .......................................3

3. Screenshot showing reproduction of user-specified program variables (cells B29:B32) on the "Input" worksheet for the Purge Analyzer Tool .....................................

4. Screenshot showing reproduction of output fields (cells B15:B26) from the "Input" worksheet for the Purge Analyzer Tool.............................................................................

5. Screenshot showing reproduction of tabular data outputted on the "Output" worksheet for the Purge Analyzer Tool...

6. Graph showing reproduction of the horizontal radial inflow graph provided on the "Output" worksheet of the Purge Analyzer Tool

7. Graph showing reproduction of the vertical velocity graph from the "Output" worksheet for the Purge Analyzer Tool.

8. Graph showing reproduction of the in-well travel time graph from the "Output" worksheet for the Purge Analyzer Tool

9. Graph showing reproduction of the aquifer fraction graph from the "Output" worksheet for the Purge Analyzer Tool

10. Screenshot showing reproduction of the "K-distribution" worksheet before layer entry for the Purge Analyzer Tool.

11. Screenshot showing reproduction of the "K-distribution" worksheet after layer entry using a rock fracture analogy where the fracture exists at the middle of the well opening for the Purge Analyzer Tool. 


\section{Conversion Factors}

U.S. customary units to International System of Units

\begin{tabular}{lcl}
\hline \multicolumn{1}{c}{ Multiply } & By & \multicolumn{1}{c}{ To obtain } \\
\hline inch (in) & Length & \\
inch (in) & 2.54 & centimeter $(\mathrm{cm})$ \\
foot (ft) & 25,400 & micrometer $(\mu \mathrm{m})$ \\
mile (mi) & 0.3048 & meter $(\mathrm{m})$ \\
\hline & 1.609 & kilometer $(\mathrm{km})$ \\
\hline ounce, fluid (fl. oz) & Volume & \\
\hline & 29.57 & milliliter $(\mathrm{mL})$ \\
\hline gallon per minute (gal/min) & Flow rate & \\
cubic inch per minute (in $\left.{ }^{3} / \mathrm{min}\right)$ & 3.785 & liter per minute $(\mathrm{L} / \mathrm{min})$ \\
cubic feet per minute (ft $\left.{ }^{3} / \mathrm{min}\right)$ & 16.39 & milliliter per minute $(\mathrm{mL} / \mathrm{min})$ \\
& 28.3168 & liter per minute $(\mathrm{L} / \mathrm{min})$ \\
\hline feet per minute (ft/min) & Velocity & \\
\hline & 0.3048 & meter per minute $(\mathrm{m} / \mathrm{min})$ \\
\hline feet per day (ft/d) & Hydraulic conductivity & \\
\hline
\end{tabular}

\section{Glossary and Abbreviations}

\begin{tabular}{|c|c|}
\hline$A_{\text {well }}$ & area of well \\
\hline$A_{\text {rad-2ft }}$ & area of mixing zone \\
\hline b & thickness or length of well opening, $\mathrm{ft}$ \\
\hline $\mathrm{dt}$ & time interval for solution to compute aquifer fractional capture, $\min$ \\
\hline DTW & depth to water from land surface datum, $\mathrm{ft}$ \\
\hline DTS & depth to top of screen from land surface datum, $\mathrm{ft}$ \\
\hline $\mathrm{D}_{\text {well }}$ & diameter of well, in inches \\
\hline HF & $\begin{array}{l}\text { heterogeneity factor, a multiple between high and low hydraulic conductivity } \\
\text { (K) of a modeled layer, dimensionless }\end{array}$ \\
\hline $\mathrm{K}_{\mathrm{avg}}$ & average hydraulic conductivity across the screen or well opening, $\mathrm{ft} / \mathrm{d}$ \\
\hline $\mathrm{K}_{\text {High }}$ & highest hydraulic conductivity per layer of the screen or well opening, $\mathrm{ft} / \mathrm{d}$ \\
\hline $\mathrm{K}_{\text {layer }}$ & hydraulic conductivity per layer, $\mathrm{ft} / \mathrm{d}$ \\
\hline $\mathrm{K}_{\text {Low }}$ & lowest hydraulic conductivity per layer, $\mathrm{ft} / \mathrm{d}$ \\
\hline $\mathrm{K}_{\text {medium }}$ & $\begin{array}{l}\text { medium hydraulic conductivity per layer of the screen or well opening as } \\
\text { determined from the average of the } \mathrm{K}_{\text {High }} \text { and } \mathrm{K}_{\text {Low' }} \text { t } \mathrm{t} / \mathrm{d}\end{array}$ \\
\hline $\mathrm{L}_{\mathrm{cw}}$ & $\begin{array}{l}\text { Length (height) of casing water under pumping conditions above top of well } \\
\text { opening, } \mathrm{ft}\end{array}$ \\
\hline $\mathrm{L}_{\mathrm{T}}$ & cell thickness or layering used to calculate radial inflow and in-well flow, $\mathrm{ft}$ \\
\hline
\end{tabular}




\begin{tabular}{|c|c|}
\hline $\mathrm{M}_{2}$ & mixing zone of pump, $\mathrm{ft}$ \\
\hline PAT & Purge Analyzer Tool \\
\hline$P_{L}$ & pump location relative to top of screen or open interval, $\mathrm{ft}$ \\
\hline $\mathrm{Q}_{\mathrm{H}}$ & horizontal radial flow within the $\mathrm{M}_{\mathrm{z}^{\prime}} ; \mathrm{ft}^{3} / \mathrm{min}$ \\
\hline $0_{h 1-n}$ & $\begin{array}{l}\text { individual layered radial flow from discretized layers (denoted as } 1-\mathrm{N} \text { ); the } \\
\text { summation of } Q_{h 1-n} \text { constitutes the } Q_{v} \text { term }\end{array}$ \\
\hline $0_{p}$ & average pumping rate, $\mathrm{L} / \mathrm{min}$ in input field \\
\hline $\mathrm{O}_{p^{\prime}}$ & adjusted average pumping rate that accounts for wellbore storage $\left(0_{w}\right), \mathrm{ft}^{3} / \mathrm{min}$ \\
\hline $0_{v}$ & $\begin{array}{l}\text { vertical flow entering the mixing zone }\left(\mathrm{M}_{\mathrm{z}}\right) \text { from the summation of layered } \\
\text { radial flow; } \mathrm{ft}^{3} / \mathrm{min}\end{array}$ \\
\hline $0_{w}$ & flow from wellbore storage, $\mathrm{ft}^{3} / \mathrm{min}$ \\
\hline $\mathrm{Re}$ & $\begin{array}{l}\text { Reynolds number, a dimensionless number used to compare the ratio of inertia } \\
\text { force to viscous force. In hydraulics it is used to assess flow turbulence. }\end{array}$ \\
\hline $\mathrm{R}_{0}$ & radius of influence, $\mathrm{ft}$ \\
\hline s & drawdown at the well, $\mathrm{ft}$ \\
\hline$S$ & storage coefficient, dimensionless \\
\hline $\mathrm{T}$ & transmissivity \\
\hline$t_{\text {purge }}$ & actual (reverse mode) or anticipated (forward mode) purge time, min \\
\hline$t_{\min }$ & $\begin{array}{l}\text { potential minimum purge time, computed from the in-well travel time based on } \\
\text { the } V \text { and the length of the well screen, } \min \end{array}$ \\
\hline V & unidirectional maximum vertical velocity (ft/min) \\
\hline $\begin{array}{l}\text { olumetric } \\
\text { urge time }\end{array}$ & $\begin{array}{l}\text { amount of purge time required to evacuate the equivalent of three-saturated } \\
\text { well volumes }\end{array}$ \\
\hline
\end{tabular}





\title{
Instructions for Running the Analytical Code PAT (Purge Analyzer Tool) for Computation of In-Well Time of Travel of Groundwater under Pumping Conditions
}

\author{
By P.T. Harte, ${ }^{1}$ B.J. Huffman, ${ }^{1}$ Tomas Perina, ${ }^{2}$ Herb Levine, ${ }^{3}$ and Daewon Rojas-Mickelson ${ }^{3}$
}

\section{Introduction}

Understanding the optimal time needed to purge a well while pumping to collect a representative groundwater sample requires an understanding of groundwater flow in wells (in-well flow). Parameters that affect in-well flow include the hydraulic properties of the aquifer, well construction, drawdown from pumping, and pump rate. The time of travel relative to in-well flow is affected by the pump's intake location. The Purge Analyzer Tool (PAT) incorporates hydraulic calculations to help assess the optimal purge times required to vertically transport groundwater in the well to the pump intake (Harte, 2017). Harte (2017) includes a discussion on the rationale for determining in-well groundwater flow and time of travel and also discusses the limitations inherent in the PAT; an understanding of the limitations is important to ensure proper use.

The PAT calculates flow by use of the Dupuit-Theim equation (Lohman, 1979) that assumes steady-state radial flow and a total inflow from the well opening or screen equal to the pumping rate (eq. 1). A bulk average hydraulic conductivity $\left(\mathrm{K}_{\mathrm{avg}}\right)$ is derived from this relationship. Once $\mathrm{K}_{\text {avg }}$ is calculated, the program calculates incremental (layered) horizontal radial inflow into the well over user defined increments (layers). These defined increments represent the screen or well opening as a fraction of the total inflow. The amount of inflow per layer is proportional to the user-defined layered distribution of hydraulic conductivity $\left(\mathrm{K}_{\text {layer }}\right)$ because drawdown is assumed to be uniformly distributed in the well. The water budget equation that guides the solution of the PAT (eq. 1) is specified as:

$$
Q_{p}=Q_{v}+Q_{H}+Q_{w}
$$

where

$Q_{P} \quad$ is pumping rate,

$Q_{v} \quad$ is vertical flow entering the boundary of the mixing zone $\left(\mathrm{M}_{\mathrm{z}}\right)$ from the summation of layered radial flow $\left(\sum Q_{h l-n}\right)$ where 1-n denotes number of layers,

$Q_{H} \quad$ is horizontal radial flow into the mixing zone $\left(\mathrm{M}_{\mathrm{z}}\right)$, and

$Q_{w} \quad$ is flow from wellbore storage effects.

The in-well flow is computed from the convergence of incremental (layered) radial inflows $\left(Q_{h 1-n}\right)$ summed to the total vertical flow $\left(Q_{V}\right)$ entering the adjacent zone to the pump intake (called mixing zone $\left[M_{z}\right]$ ) as shown in figure 1 . The $Q_{v}$ is transported as one-dimensional piston flow. Within the $\mathrm{M}_{\mathrm{z}}$, it's assumed that flow to the pump is dominated by horizontal radial flow $\left(\mathrm{Q}_{\mathrm{H}}\right)$ when the pump is in the open interval of the well. Flow from the wellbore storage $\left(Q_{w}\right)$ is computed from the volume of water pumped from the well at the time of the drawdown (s) measurement(s). Aquifer storage effects are unaccounted for but are likely to be problematic when (1) dewatering within the well opening occurs or (2) when the water table is close to the top of the well screen or open interval where additional flow into the upper portion of the well opening may occur. For fully saturated wells tens of feet below the water table, storage effects are likely to be more uniformly distributed across the well screen or open interval (regardless of confined or unconfined conditions). Therefore, radial inflow from storage will be less prominent under pump rates commonly used in groundwater sampling either for volumetric sampling ( $<3$ gallons per minute) or low-flow sampling $(<0.5$ liters per minute).

A major benefit of the use of the PAT is the understanding of time-varying, vertical integration of captured pump water. The analytical model computes aquifer (formation) capture intervals relative to the open interval of the well. This information is displayed graphically (called aquifer fraction graphs) and can be used to assess the likely formation intervals contributing water to the sample at any time.
${ }^{1}$ U.S. Geological Survey.

${ }^{2} \mathrm{APTIM}$, Inc.

${ }^{3}$ U.S. Environmental Protection Agency. 


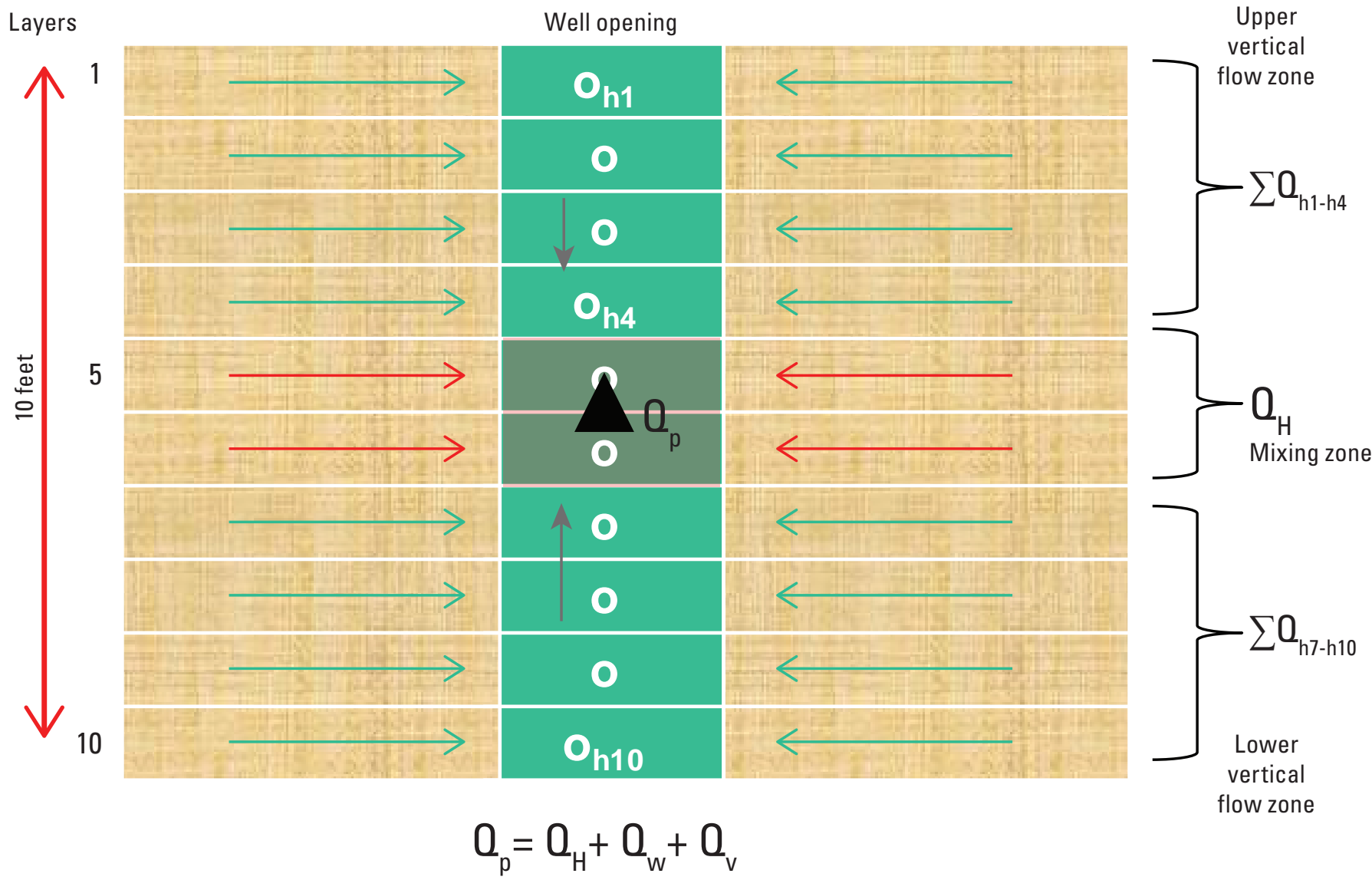

where,

$0_{p}=$ Pumping rate,

$\mathrm{Q}_{\mathrm{H}}=$ Flow into the mixing zone $(\mathrm{Mz})$,

$0_{w}=$ Flow from well storage depletion rate, and

$\mathrm{Q}_{\mathrm{w}}=$ Vertical flow external to the $\mathrm{Mz}$ and calculated from

the $\sum \mathrm{Q}_{\mathrm{hl-n}}$ summation of incremental layered radial flow

Figure 1. Schematic of the allocation of flow in the well while pumping for the Purge Analyzer Tool.

\section{Contents of Program}

The PAT is contained within a macro-enabled Microsoft Excel file with a *.xlsm extension. Contained in the Excel file are multiple worksheets. There are three worksheets for the case of homogeneous hydraulic conductivity ( $\mathrm{K}_{\text {layer }}$ is uniform) and an additional worksheet if a heterogeneous condition ( $\mathrm{K}_{\text {layer }}$ is nonuniform) is simulated. The operation of the analytical model is discussed in the "Operation" section.

\section{Requirements}

The PAT (Purge Analyzer Tool) is a Microsoft Excel VBA macro code for computation of in-well travel times of groundwater under pumping from wells. Excel versions dated 2016, 2013, or 2010 are required. For Excel 2007, certain functions to display charts will not work. Many commands that do not work in Excel 2007 are associated with the charts aesthetic nature and can be commented out by adding a single quote (') to the beginning of the command line in the embedded VBA macro called "HV_Pump_Flow." Most users (permission dependent) will be able to open the VBA macro by going to the Developer tab, selecting macro, and then selecting the VBA macro called "HV_Pump_Flow" under the module where macros are stored.

Excel files must be saved as a macro enabled .xlsm workbook. On certain computer systems, the user will need to open the file and then resave the macro-enabled Excel file under a new name to meet security requirements.

The Data Solver Add-ins in Excel must be enabled for VBA code operation. For many computer systems, the default configuration is likely to be disabled. There are several methods to check if Solver is enabled including on the "Data" tab 
of an Excel workbook (if it is visible on the ribbon); under "Add-Ins" of the options menu under the "File" tab; and on the "Developer" tab under the "Excel Add-ins" menu. It may also be necessary to ensure that the "Developer" tab is shown on the command toolbar along with the "Add-ins" ribbon. This is done by selecting "Options" under "File" drop-down tab. Under options select "Customize Ribbon" and check "Developer" and "Add-ins" to make them viewable in the "Main Tabs" ribbon. In the new window, click the "Tools" tab and click on "References." The box next to "Solver Add-ins" must be checked. Go back to the "Developer" tab and click on "Excel-Add-ins." The "Data Solver Add-ins" should now be checked. After ensuring the "Data Solver Add-ins" is invoked, save the workbook using the macro-enabled .xlsm suffix.

\section{Instructions}

This and the following sections explain the general operational steps of the program for reverse and forward mode in the instructional worksheet. Normally, the PAT is used in reverse mode where field data were collected and the $\mathrm{K}_{\text {avg }}$ is unknown but can be calculated. In this case, some vertical flow is assumed to occur based on the relations specified in equation 1 because of the division of flow between $Q_{H}$ in the $M_{z}$ and the flow in the rest of the screen or open interval outside of the $\mathrm{M}_{\mathrm{z}}$ where $\left(\mathrm{Q}_{\mathrm{v}}\right)$ is computed and tracked. However, if $\mathrm{K}_{\text {avg }}$ is known from prior information then the PAT can be used in forward mode to assess the likelihood of $Q_{v}$ occurring in the well. In other words, for a given drawdown, the programs checks if there is sufficient $Q_{H}$ in the $M_{z}$ to satisfy the adjusted pump rate $\left(\mathrm{Q}_{\mathrm{p}}\right)$; under this case $\mathrm{Q}_{\mathrm{v}}$ approaches zero. The macro (RUN MODEL button) is not invoked in this case because $\mathrm{K}_{\mathrm{avg}}$ is already known.

\section{Input Worksheet}

Data are entered under the worksheet labeled "Input" of the *.xlsm Excel file. Input parameters that describe well purging, well construction, and water levels are specified in the gray shaded cells B4:B13 (fig. 2). The depth to water (DTW; cell B6) is the static water level in feet (ft) below land surface. The depth to screen or open interval (DTS; cell B7) is the top of the well opening in $\mathrm{ft}$ below land surface. The length of the screen $\left(\mathrm{L}_{\mathrm{s}}\right)$ is the difference in $\mathrm{ft}$ between the top and bottom of the well opening. The diameter of the well $\left(\mathrm{D}_{\text {well }}\right)$ is for the well opening. If the well casing diameter differs from the opening, then a correction factor can be applied to the drawdown (s) cell B12. Values in cells B10:B12 should represent data that were collected contemporaneously. The anticipated purge time $\left(\mathrm{t}_{\text {purge }}\right.$; cell B10) and drawdown ( $\mathrm{s}$; in cell B12) are used in the $\mathrm{Q}_{\mathrm{w}}$ calculation for wellbore storage depletion rate. The assumption is that the drawdown has stabilized.

The heterogeneity factor (HF) is an important parameter to simulate homogeneous $(\mathrm{HF}=1)$ or heterogeneous

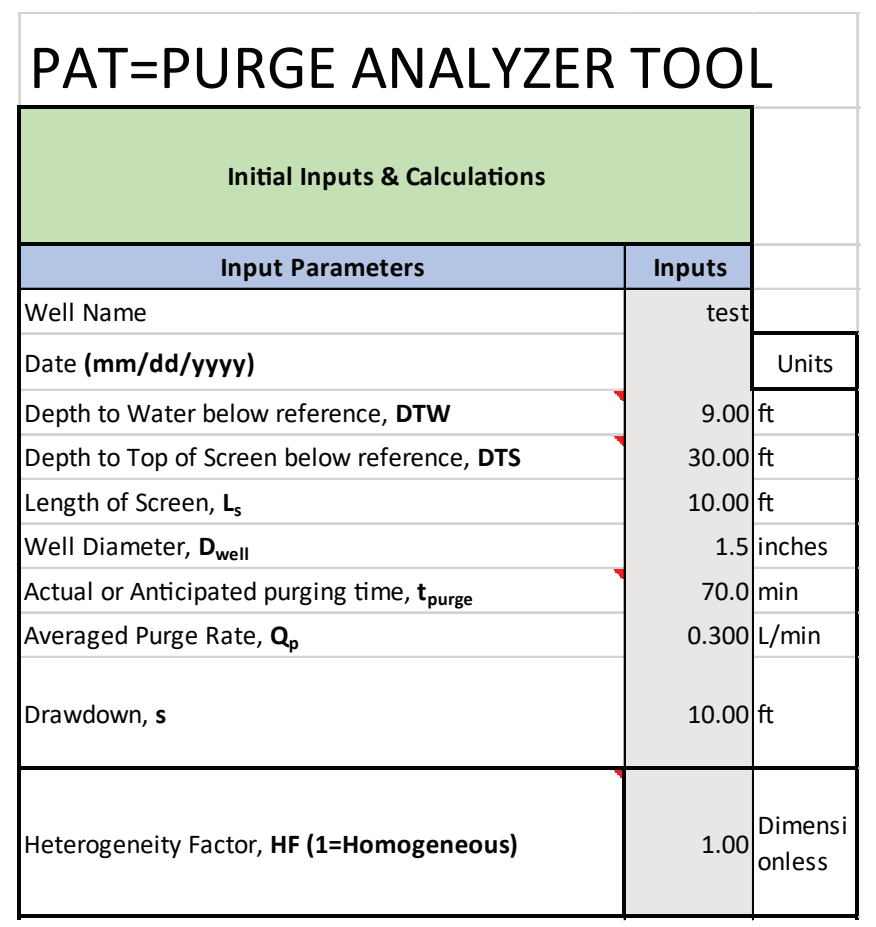

Figure 2. Reproduction of user-specified input parameters (cells B4:B14) on the "Input" worksheet for the Purge Analyzer Tool. [ft, feet; min, minutes; L/min, liters per minute]

conditions (HF greater than 1). HF (cell B13) is specified as a multiple between the lowest and highest hydraulic conductivity of an individual layer $\left(\mathrm{K}_{\text {layer }}\right)$ encountered along the well opening. For example, if a multiple of 10 is specified as a value of $\mathrm{HF}$, the highest $\mathrm{K}_{\text {layer }}$ would be 10 times the lowest $\mathrm{K}_{\text {layer }}$. The thickness in which $\mathrm{K}_{\text {layer }}$ can vary is set depending on the layer thickness $\left(\mathrm{L}_{\mathrm{T}}\right)$. For homogeneous conditions, the $\mathrm{K}_{\text {layer }}$ of individual layers will be uniform and equal to $\mathrm{K}_{\text {avg }}$. For heterogeneous conditions, specifying a multiplier greater than 1 allows for layered variability in $\mathrm{K}_{\text {layer }}$ that is constrained by the multiple factor specified in cell B13. An initial estimate of $\mathrm{K}_{\text {avg }}$ can be entered in cell B14, however once the program is run in reverse mode the field will be updated to the calibrated value. See the "Operation" section of this report for additional details.

Additional input parameters to run the PAT (fig. 3; cells B29:B32) are the pump intake position $\left(\mathrm{P}_{\mathrm{L}}\right)$ relative to the top of the screen or well open interval; the length of the $M_{z}$ above or below the pump intake (specified as $1 / 2 \mathrm{M}_{\mathrm{z}}$ in the PAT); a layering thickness $\left(\mathrm{L}_{\mathrm{T}}\right)$ to compute $\mathrm{Q}_{\mathrm{H}}$ into the well; and time discretization $(\mathrm{dt})$ for the determination of aquifer capture (fig. 3).

The depth of the $\mathrm{P}_{\mathrm{L}}$ within the well screen or open interval is specified by positive distances from the top of the well screen or open interval. For $\mathrm{P}_{\mathrm{L}}$ within the casing, negative distances are specified. The middle point of the pump intake should be used for its pump position. 


\begin{tabular}{|l|r|l|}
\hline \multicolumn{1}{|c|}{ Program Variables } & Inputs & Units \\
\hline $\begin{array}{l}\text { Pump Location relative to top of screen (Above } \\
\text { screen specify negative number for absolute } \\
\text { distance), } \mathbf{P}_{\mathbf{L}}\end{array}$ & & \\
$\begin{array}{l}\text { 1/2 Mixing Zone Buffer length above/below pump } \\
\text { intake, } 1 / 2 \mathbf{M}_{\mathbf{z}}\end{array}$ & 0.5 & $\mathrm{ft}$ \\
$\begin{array}{l}\text { Cell Thickness of layers to compute horizontal radial } \\
\text { flow, } \mathbf{L}_{\mathbf{T}}\end{array}$ & 0.5 & $\mathrm{ft}$ \\
$\begin{array}{l}\text { Time interval (dt) for computation of flow and Aquifer } \\
\text { Fraction graph }\end{array}$ & 0.5 & $\mathrm{~min}$ \\
\hline
\end{tabular}

Figure 3. Reproduction of user-specified program variables (cells B29:B32) on the "Input" worksheet for the Purge Analyzer Tool. [ft, feet; min, minutes]

The $\mathrm{M}_{\mathrm{z}}$ is the vertical length of the saturated water column surrounding the pump intake. In $\mathrm{M}_{z}$, inflow into the well is proportioned to the $\mathrm{Q}_{\mathrm{H}}$ term (eq. 1). As the vertical flow crosses into the $\mathrm{M}_{\mathrm{z}}$ boundary (or boundaries), no computation of vertical travel time occurs, and flow is assumed as instantaneously evacuated. Therefore, vertical transport is computed to the edge of the $\mathrm{M}_{\mathrm{z}}$. The computation of $\mathrm{Q}_{\mathrm{H}}$ is set to zero when the pump intake is located in the well casing as no radial flow can contribute in $\mathrm{M}_{\mathrm{z}}$. At a minimum, the $\mathrm{M}_{\mathrm{z}}$ corresponds to the length of the pump intake. For a pump intake length of approximately $1 \mathrm{ft}$ or less, a value of $0.5 \mathrm{ft}$ for the $1 / 2 \mathrm{M}_{\mathrm{z}}$ length (distance above and below the midpoint of the pump intake) can be specified in the PAT. For high pump rates, an $\mathrm{M}_{\mathrm{z}}$ extended beyond the length of the intake is likely desirable because of turbulence. A $1 / 2 \mathrm{M}_{\mathrm{z}}$ value of $0.5 \mathrm{ft}$ is recommended for most pump intakes that are less than 0.8 -ft long. The $\mathrm{M}_{\mathrm{z}}$ affects the vertical time of travel computations and the time of aquifer fraction captured because vertical transport is only calculated up to the $\mathrm{M}_{\mathrm{z}}$ boundary (or boundaries). This is regardless if the $\mathrm{P}_{\mathrm{L}}$ is in the casing or well opening (appendix 1).

$\mathrm{L}_{\mathrm{T}}$ is used to vertically discretize the saturated water column to compute horizontal flow and corresponding vertical flow over the user-defined distances. The $\mathrm{L}_{\mathrm{T}}$ should be equal to or less than the $M_{z}$ length and the $M_{z}$ should be a divisible by $\mathrm{L}_{\mathrm{T}}$ with no remainder, although a nondivisible $\mathrm{L}_{\mathrm{T}}$ specification will still work. For example, if there is a $\mathrm{M}_{\mathrm{z}}$ of 0.5 , a $\mathrm{L}_{\mathrm{T}}$ of 0.1 or 0.25 would be acceptable.

Specification of the dt allows for higher or lower resolution of the vertical time of travel computation. This allows for a higher resolution discretization of the aquifer fraction graph. The smaller the dt, the smoother the aquifer fraction graph will appear. Specification of a dt that is too small will result in a longer solution runtime. The user can initially specify a relatively large dt (2 minutes) and reduce in subsequent simulations if the aquifer fraction graph appears irregular or nonsmooth.
There are other cells in the "Input" worksheet that are not related to input parameters but are cells reserved for calculation and description of parameters. The cells B15:C16 (fig. 4) are reserved for forward mode only when manual specification of $\mathrm{K}_{\text {avg }}$ is input into cell B14 and the reverse mode is not invoked ("RUN MODEL" Button on "Input" worksheet is not used). In forward mode, whether $Q_{v}$ occurs in the well for any given $Q_{p}$, is dependent on whether $Q_{H}$ for the assigned $M_{z}$ is sufficient to satisfy the $Q_{p}$, pump rate. Forward mode is further discussed in the "Operation" section.

Cells in B18:B26 are calculated by the program and listed under the column heading "Outputs" (fig. 4). The minimum potential equilibrium pump rate, in cell B18, is the summed flow from $Q_{H}$ and $Q_{v}$ in cubic feet per minute. The minimized residual as determined by Excel's solver when running the PAT in reverse mode can be seen in cell B19. This minimized residual is the difference between the minimum potential equilibrium pump rate (cell B18) and the $\mathrm{Q}_{\mathrm{p}^{\prime}}\left(\mathrm{Q}_{\mathrm{p}}\right.$ minus $\left.\mathrm{Q}_{\mathrm{w}}\right)$. The minimized residual should be close to zero. Additional discussion on Excel solver use is included in the "Solver" section of the report. The observed $\mathrm{Q}_{\mathrm{w}}$ (cell B20) represents the volume of water in the well removed by the drawdown (s). The maximum vertical wellbore velocity (V; cell B21) assumes unidirectional flow and is computed from $\mathrm{Q}_{\mathrm{p}}$, divided by the wellbore cross-sectional area. An external check on flow can be done using the value from cell B21 in the Reynolds equation (Streeter and Wylie, 1985) to check against the potential for turbulent flow, by calculating the Reynolds number (Re), where the laminar flow regime holds for cases of $\operatorname{Re}<2,000$. The adjusted maximum vertical wellbore velocity, in cell B22,

\begin{tabular}{|c|c|c|c|}
\hline A & A & B & $C$ \\
\hline 16 & $\begin{array}{l}\text { Is vertical flow in well likely induced from purging, } \\
\text { based on estimated radial flow in } \mathbf{M}_{\mathbf{z}} \text { ? (Forward } \\
\text { mode) }\end{array}$ & \multicolumn{2}{|c|}{ YES } \\
\hline 17 & Calculated Parameters & Outputs & Units \\
\hline 18 & Minimum potential equilibrium purge rate & 0.0085 & $\mathrm{ft}^{3} / \mathrm{min}$ \\
\hline 19 & Difference between Radial flow - Purge Rate & 0.0000 & $\mathrm{ft}^{3} / \mathrm{min}$ \\
\hline 20 & Observed wellbore storage volume & 0.1227 & $\mathrm{ft}^{3}$ \\
\hline 21 & $\begin{array}{l}\text { Maximum potential vertical wellbore velocity with } \\
\text { no well storage }\end{array}$ & 0.8613 & $\mathrm{ft} / \mathrm{min}$ \\
\hline 22 & $\begin{array}{l}\text { Adjusted maximum potential vertical wellbore } \\
\text { velocity including well storage and horizontal flow } \\
\text { into the } \mathrm{Mz}\end{array}$ & 0.6947 & $\mathrm{ft} / \mathrm{min}$ \\
\hline 23 & Potential minimum purge time & 28.8 & $\min$ \\
\hline 24 & Volumetric purge time & 107.7 & $\min$ \\
\hline 25 & Transmissivity of well screen or open interval, $\mathbf{T}$ & 1.0044 & $\mathrm{ft}^{2} / \mathrm{day}$ \\
\hline 26 & Average $\mathrm{K}$ of well screen or open interval, $\mathbf{K}_{\text {avg }}$ & 0.1004 & $\mathrm{ft} / \mathrm{day}$ \\
\hline
\end{tabular}

Figure 4. Reproduction of output fields (cells B15:B26) from the "Input" worksheet for the Purge Analyzer Tool. [ $\mathrm{ft}^{3} / \mathrm{min}$, cubic feet per minute; $\mathrm{ft}$, feet; min, minute; $\mathrm{ft}^{2} / \mathrm{day}$, square feet per day] 
includes the $\mathrm{Q}_{\mathrm{w}}$ that occurs during $\mathrm{t}_{\text {purge }}$. The potential minimum purge time $\left(\mathrm{t}_{\min }\right.$; cell B23) is computed from the in-well travel time based on $\mathrm{V}$ and the $\mathrm{L}_{\mathrm{s}}$ The purge time required to remove three well casing volumes of water (volumetric purge time) is provided in cell B24 for comparison. The transmissivity (T) for the well opening (cell B25) is $\mathrm{K}_{\text {avg } *} \mathrm{~L}_{\mathrm{s}}$. Both $\mathrm{K}_{\text {avg }}$ and $T$ are representative of the well opening length $\left(\mathrm{L}_{\mathrm{s}}\right)$ and not the aquifer thickness.

\section{Output Worksheet}

The "Output" worksheet lists the results of the PAT in reverse mode (fig. 5). Columns A through J list tabular data related to radial flow, vertical velocity, and travel time to the $\mathrm{P}_{\mathrm{L}}$ bounded by the $\mathrm{M}_{\mathrm{z}}$. Column $\mathrm{A}$ lists the index number for each discretized layer whereas columns B and C list the centroid position and radial inflow corresponding to the index number. Column D lists the index number for each vertical face between the discretized layers. Column E lists the vertical face position, and column F lists the vertical velocity calculated corresponding to the index number in column D. Column $\mathrm{G}$ lists the linear travel time, and column $\mathrm{H}$ lists the travel time accounting for acceleration. Column I lists the time since the start of pumping, and column $J$ lists the fraction of inflow from recharge (aquifer) captured by the pump divided by the total inflow into the well from the formation.

There are four graphs displayed on the "Output" worksheet. They include the horizontal radial flow graph (fig. 6), the vertical velocity graph (fig. 7), the in-well travel time to the $M_{z}$ (fig. 8), and the aquifer fraction graph (fig. 9). For graphs in figures $6-8$, the ordinate tick marks and labels correlate to the $\mathrm{L}_{\mathrm{T}}$ specified on the "Input" worksheet; in this case, an $\mathrm{L}_{\mathrm{T}}$ of $0.25 \mathrm{ft}$ was specified. All output figures displayed in this report are for conditions specified in the input fields shown in figures 2 and 3.

In the example provided (fig. 6), the well inflow is uniform for a homogeneous condition. The pump intake is set at the middle of the well screen as delineated by $\mathrm{M}_{\mathrm{z}}$ (fig. 6; green lines). No inflow occurs in the well casing as noted by zero inflow (fig. 6; red dotted line) above the top of the opening (fig. 6; black dashed line). Figures 7 and 8 also show the location of $\mathrm{M}_{\mathrm{z}}$ and the top of the well opening.

Figures 7 and 9 show the vertical velocity and in-well travel times, respectively, under a homogeneous case. For a homogeneous condition where the pump is set at the middle of the well opening, radial flow, vertical velocity, and in-well travel time are symmetric. Both the linear velocity and acceleration velocity schemes are provided in figure 8 ; the acceleration velocity is used in the calculation of capture.

Figure 9 compares the fraction of inflow from the aquifer during pumping (red line) to the actual (reverse mode) or anticipated (forward mode) purge time (gray line) and the purging time required to remove three-casing volumes of water from the well (orange line). The purge time associated with the aquifer fraction needed to collect a representative sample is defined by the travel time to vertically

\begin{tabular}{|l|l|l|l|l|l|l|l|l|l|}
\hline A & B & C & D & E & F & G & H & I & J \\
\hline $\begin{array}{l}\text { Index } \\
\text { Number }\end{array}$ & $\begin{array}{l}\text { Centroid } \\
\text { Position } \\
\text { (ft from } \\
\text { top of } \\
\text { opening) }\end{array}$ & $\begin{array}{l}\text { Radial } \\
\text { Flow } \\
\text { (ft'/min) }\end{array}$ & $\begin{array}{l}\text { Index } \\
\text { Number }\end{array}$ & $\begin{array}{l}\text { Vertical } \\
\text { Face } \\
\text { Position } \\
\text { (ft from } \\
\text { top of } \\
\text { opening) }\end{array}$ & $\begin{array}{l}\text { Vertical } \\
\text { Velocity } \\
\text { (ft/min) }\end{array}$ & $\begin{array}{l}\text { Travel } \\
\text { Time } \\
\text { (min) }\end{array}$ & $\begin{array}{l}\text { Travel } \\
\text { Time } \\
\text { (accel) } \\
\text { (min) }\end{array}$ & $\begin{array}{l}\text { Purge } \\
\text { Time } \\
\text { (min) }\end{array}$ & $\begin{array}{l}\text { Aquifer } \\
\text { Fraction } \\
\text { (ratio) }\end{array}$ \\
\hline 0 & -11.00 & 0.0000 & 0 & -11.00 & 0.00 & --- & --- & 0.0 & 0.00 \\
\hline 1 & -10.88 & 0.0000 & 1 & -10.75 & 0.00 & --- & --- & 0.5 & 0.10 \\
\hline 2 & -10.63 & 0.0000 & 2 & -10.50 & 0.00 & --- & --- & 1.0 & 0.15 \\
\hline 3 & -10.38 & 0.0000 & 3 & -10.25 & 0.00 & --- & --- & 1.5 & 0.15 \\
\hline 4 & -10.13 & 0.0000 & 4 & -10.00 & 0.00 & --- & --- & 2.0 & 0.20 \\
\hline 5 & -9.88 & 0.0000 & 5 & -9.75 & 0.00 & --- & -- & 2.5 & 0.20 \\
\hline 6 & -9.63 & 0.0000 & 6 & -9.50 & 0.00 & --- & --- & 3.0 & 0.25 \\
\hline 7 & -9.38 & 0.0000 & 7 & -9.25 & 0.00 & --- & --- & 3.5 & 0.25 \\
\hline 8 & -9.13 & 0.0000 & 8 & -9.00 & 0.00 & --- & --- & 4.0 & 0.30 \\
\hline 9 & -8.88 & 0.0000 & 9 & -8.75 & 0.00 & --- & --- & 4.5 & 0.30 \\
\hline 10 & -8.63 & 0.0000 & 10 & -8.50 & 0.00 & --- & --- & 5.0 & 0.35 \\
\hline 11 & -8.38 & 0.0000 & 11 & -8.25 & 0.00 & --- & --- & 5.5 & 0.35 \\
\hline 12 & -8.13 & 0.0000 & 12 & -8.00 & 0.00 & --- & --- & 6.0 & 0.40 \\
\hline
\end{tabular}

Figure 5. Reproduction of tabular data outputted on the "Output" worksheet for the Purge Analyzer Tool. [ft, foot; $\mathrm{ft}^{3} / \mathrm{min}$, cubic foot per minute; $\mathrm{ft}^{2} / \mathrm{min}$, square foot per minute] 


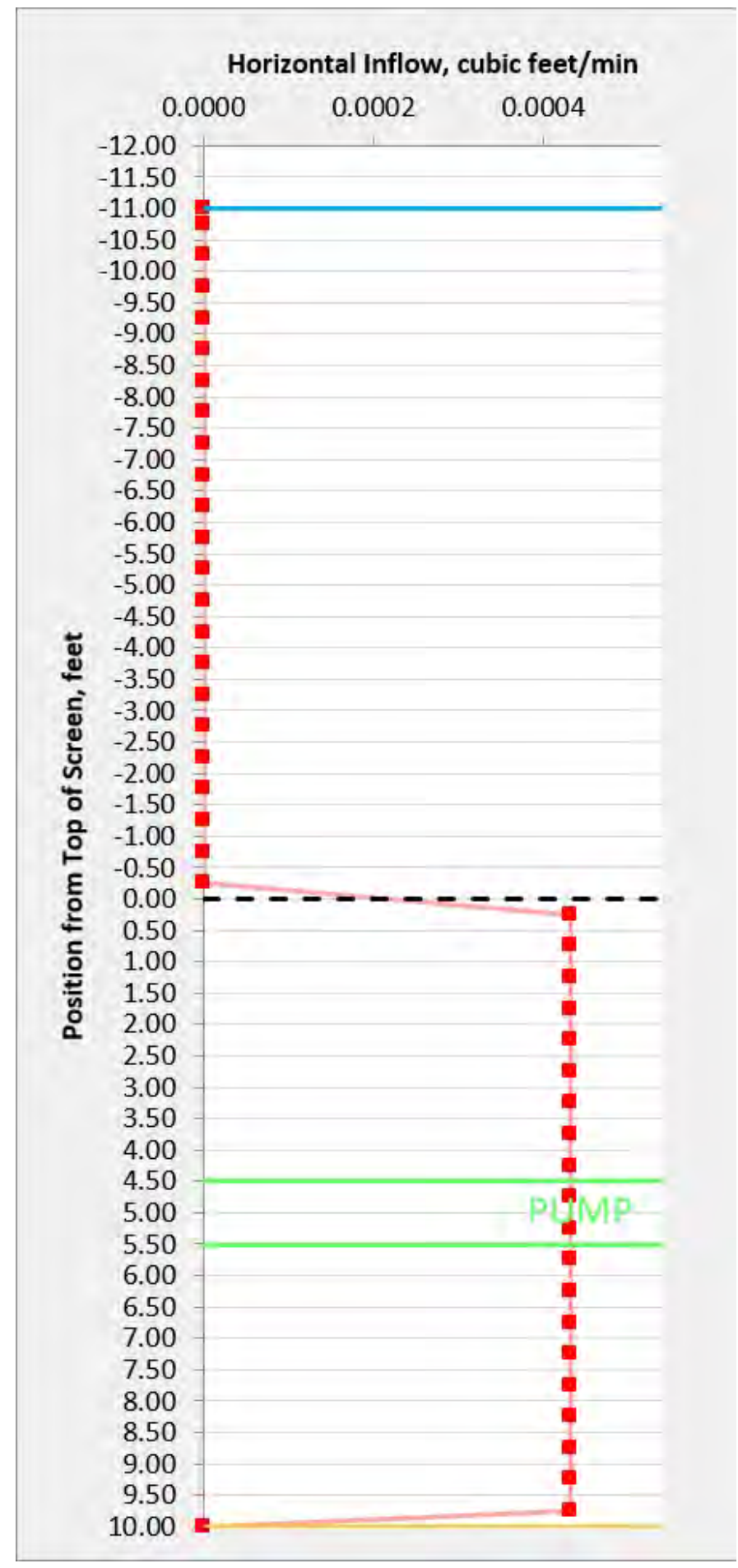

Figure 6. Reproduction of the horizontal radial inflow graph provided on the "Output" worksheet of the Purge Analyzer Tool. Example from a homogeneous condition. Simulated horizontal flow is uniform as denoted by the red dots and line. [cubic feet/ min, cubic feet per minute]

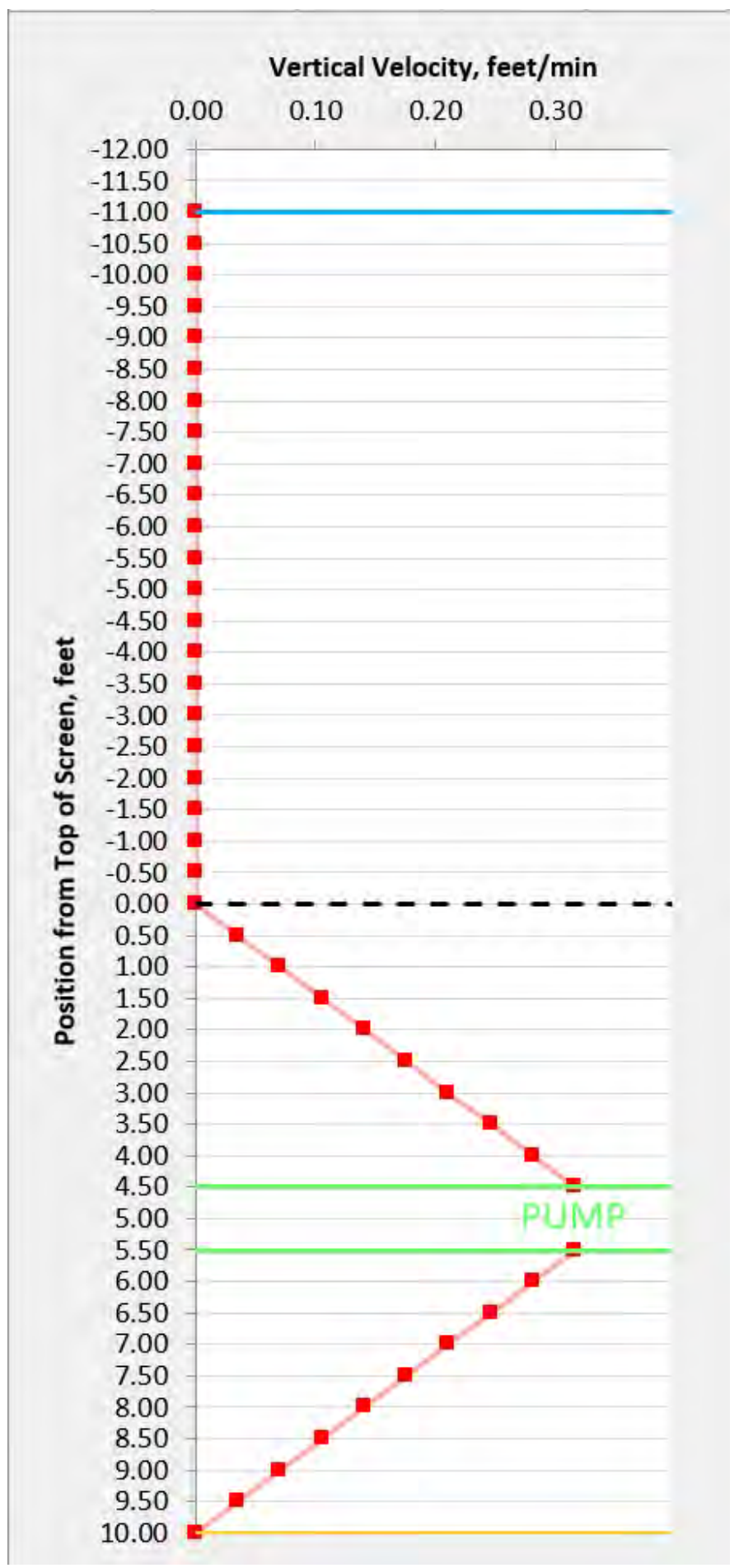

Figure 7. Reproduction of the vertical velocity graph from the "Output" worksheet for the Purge Analyzer Tool. Example from a homogeneous condition where uniform well inflow occurs. Vertical flow (red line) to the mixing zone (parameter $\mathrm{M}_{z^{\prime}}$ green line) is symmetric if the pump intake (parameter $P_{L}$ ) is set at the middle of the well opening. [feet/min, feet per minute] 


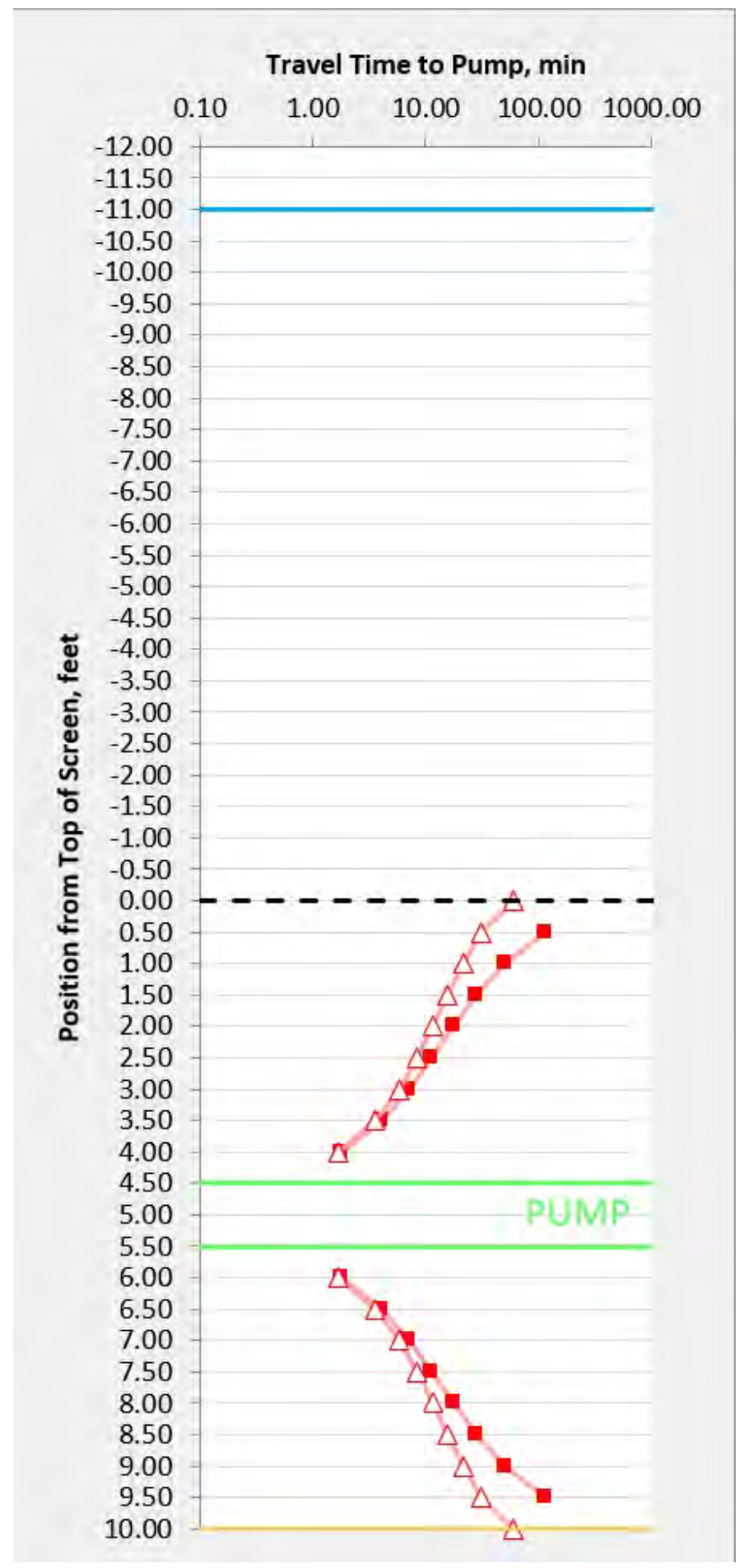

Figure 8. Reproduction of the in-well travel time graph from the "Output" worksheet for the Purge Analyzer Tool. Example from a homogeneous condition and pump intake at the middle of the well opening showing linear velocity and corrected for acceleration. For in-well travel time, the regular linear velocity (solid red square) and velocity corrected for acceleration (open red triangle) are shown for reference. Travel times computed when accounting for acceleration are significantly faster further from the mixing zone $\left(\mathrm{M}_{\mathrm{z}^{\prime}}\right.$ green line). [min, minute] 


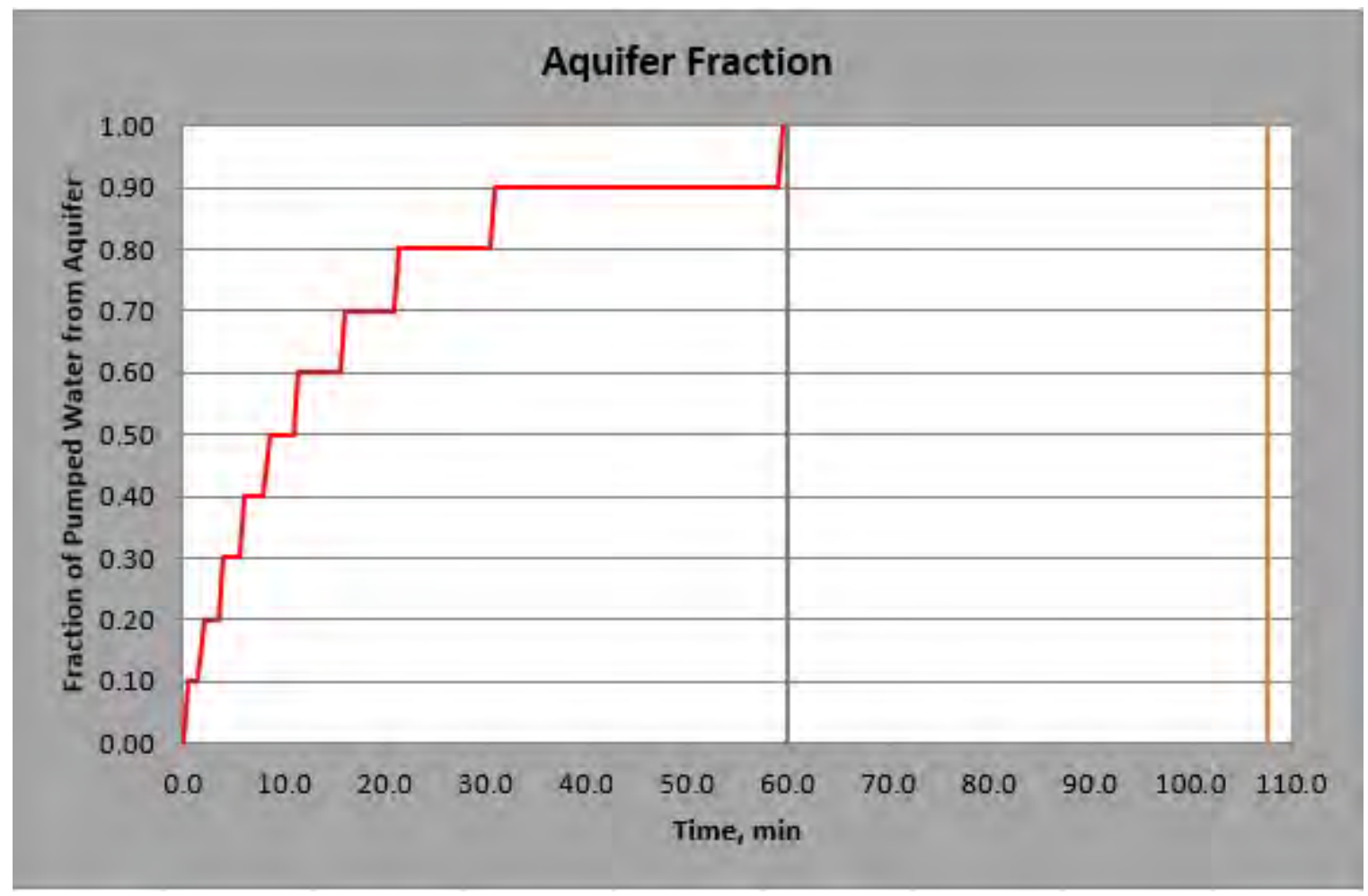

Figure 9. Reproduction of the aquifer fraction graph from the "Output" worksheet for the Purge Analyzer Tool. Example from a homogeneous condition and pump intake at the middle of the well opening. The red line is travel time to pump capture as calculated from the Purge Analyzer Tool, the gray line is the specified purge time, and the solid vertical orange line is the volumetric sample time from the extraction of the equivalent pumped volume of three well casings. [min, minutes]

transport inflow along the entire well opening; in this case at 60 mins (fig. 9). In contrast, the purge time needed to extract three-casing volumes of water is 107 mins (fig. 9). For sample collection purposes, if field parameters stabilize after $60 \mathrm{mins}$, the PAT indicates a representative sample can be collected anytime afterwards.

\section{Operation}

The PAT can be run in reverse (calculation of $\mathrm{K}_{\text {avg }}$ ) or forward mode (user-specified $\mathrm{K}_{\mathrm{avg}}$ ). For the reverse mode, the Excel solver is automated and executed from within the program. Additional information on the subject is discussed in the "Solver" section of the report.

\section{Reverse Mode}

Reverse-mode execution is invoked by clicking on the "RUN MODEL" button on the "Input" worksheet. If an HF of 1 is specified, then the program will terminate on the "Output" worksheet, otherwise an intermediate step is involved. In this step, the PAT active worksheet is moved to the " $\mathrm{K}$-Distribution" worksheet where the distribution of $\mathrm{K}_{\text {layer }}$ will be defined.

\section{Option 1: Homogeneous (HF = 1)}

The PAT brings the user directly to the "Output" worksheet when $\mathrm{HF}=1$. Each layer's $\mathrm{K}_{\text {layer }}$ is set equal to $\mathrm{K}_{\mathrm{avg}}$. Regardless of whether homogeneous conditions are simulated, the PAT will display homogeneous conditions (red line) as a reference on the graphs plotted in the "Output" worksheet.

\section{Option 2: Heterogeneous Conditions (HF > 1)}

When HF $>1$, the PAT takes the user to a worksheet called "K-Distribution." This intermediate step requires the user to specify a distributional pattern for each $\mathrm{K}_{\text {layer }}$ assigned to each discretized cell. The range allowed for any $\mathrm{K}_{\text {laver }}$ is calculated based on the HF entered at the "Input" worksheet, and the calculated $\mathrm{K}_{\mathrm{avg}}$ for the screen or open interval is also on the "Input" worksheet. The calculations for the allowable values, highest hydraulic conductivity $\left(\mathrm{K}_{\text {high }}\right)$, middle hydraulic conductivity $\left(\mathrm{K}_{\text {medium }}\right)$, and low hydraulic conductivity $\left(\mathrm{K}_{\text {low }}\right)$ 
are shown in equations 3 and 4 . The $\mathrm{K}_{\text {medium }}$ is allowed to vary by \pm 50 percent of the calculated $\mathrm{K}_{\text {avg }}$. An example of the "K-Distribution" worksheet is shown in figures 10 and 11.

$$
\begin{gathered}
K_{\text {medium }}=\frac{K_{\text {high }}+K_{\text {low }},}{2}, \\
K_{\text {high }}=H F^{*} K_{\text {low }}
\end{gathered}
$$

Once at the "K-Distribution" worksheet, the user can select a distribution of $\mathrm{K}_{\text {layer }}$ from the drop-down menu in cells D2:E2 (fig. 10). Values of $\mathrm{K}_{\text {layer }}$ are specified in absolute hydraulic conductivity units. There are eight different $\mathrm{K}_{\text {layer }}$ patterns to select from (oscillating formation, rock fracture at top of well opening, rock fracture at middle of well opening, rock fracture at bottom of well opening, double rock fracture, bimodal formation, trimodal formation, and randomized formation). With a pattern selected, the user must hit the "Populate" button (cells D1:E1, to have $\mathrm{K}_{\text {layer }}$ pattern automatically designated within the worksheet. It also is possible to specify a user-defined pattern where each layer can be manually entered a value of " $\mathrm{L}$ " $\left(\mathrm{K}_{\text {low }}\right)$, "M" $\left(\mathrm{K}_{\text {medium }}\right)$ or " $\mathrm{H}$ " $\left(\mathrm{K}_{\text {high }}\right)$ in column A under the heading "K Type." In this case, the "Populate" button is not invoked. Before continuing with the program, the "Residual" button ("Resolve Error" button) and then the "Done with the Script" button (cells H1:J1) must be invoked. After hitting the "Done with the Script" button, the program continues and ends on the "Output" worksheet.

An example of a populated $\mathrm{K}_{\text {layer }}$ distribution is shown in figure 11. After the $\mathrm{K}_{\text {layer }}$ values have been populated or manually entered, the user must click the "Resolve Error" button (cells D3:E3) to minimize the difference between the bulk average of the $\mathrm{K}_{\text {layer }}$ distribution and $\mathrm{K}_{\text {avg }}$ computed on the "Input" worksheet. Some variation (up to 10 percent) is allowed between the summation average of the specified $\mathrm{K}_{\text {layer }}$ and the $\mathrm{K}_{\mathrm{avg}}$. This is done to facilitate solution under heterogeneous conditions and from a practical standpoint to acknowledge an appropriate level of precision in the computed $\mathrm{K}_{\text {layer }}$. To continue the PAT, the user then hits the "Done! Continue Script" button (cells H4:J5) to complete the task and move to the "Output" worksheet.

\section{Forward Mode}

For forward-mode processing, the user specifies the known $\mathrm{K}_{\text {avg }}$ in cell $\mathrm{B} 14$ of the "Input" worksheet. The $\mathrm{Q}_{\mathrm{H}}$ from the Dupuit-Theim equation is calculated within the associated $\mathrm{M}_{\mathrm{z}}$ using $\mathrm{K}_{\text {avg }}$ and compared against the $\mathrm{Q}_{\mathrm{p}}$, to assess if $\mathrm{Q}_{\mathrm{v}}$ outside $\mathrm{M}_{\mathrm{z}}$ can take place. A "NO" is shown in cells B15:C16 of the "Input" worksheet when it is unlikely that $\mathrm{Q}_{\mathrm{v}}$ in the well is dominant, as discussed in Harte (2017). Note that if the $P_{L}$ is in the casing, $Q_{v}$ is assured. When the solver is invoked (reverse mode), the solver minimizes differences between the $\mathrm{Q}_{\mathrm{p}}$, and the combined flow from $\mathrm{Q}_{\mathrm{H}}$ and $\mathrm{Q}_{\mathrm{v}}$. Therefore, for the reverse mode, the default assumption is some $\mathrm{Q}_{\mathrm{v}}$ contributes to satisfying $Q_{p}$,.

\section{Solver}

The Excel data solver is embedded into the PAT macro and is invoked in reverse mode to reduce the residual (specified in cell B19 in the "Input" worksheet) between $\mathrm{Q}_{\mathrm{p}}$, and the summation of $\mathrm{Q}_{\mathrm{H}}$ and $\mathrm{Q}_{\mathrm{v}}$ by altering $\mathrm{K}_{\text {avg }}$. The lowest $\mathrm{K}_{\text {avg }}$ value allowed is $0.01 \mathrm{ft}$ per day. Values $<0.01 \mathrm{ft}$ per day are primarily affected by aquifer storage during sampling and the PAT does not calculate aquifer storage.

The generalized reduced gradient nonlinear solver option with forward derivatives is used with a convergence criterion of 0.0001 . This method looks at the gradient or slope of the objective function as the input values or decision variables change and determines if an optimum solution is reached when the partial derivatives equal zero. Of the two nonlinear solving methods, generalized reduced gradient nonlinear is the fastest. However, the solution derived from this algorithm is highly dependent on the initial conditions and may not be the global optimum solution. The solver may stop at the local optimum value nearest to the initial conditions, giving the user a solution that may or may not be optimized globally (Engineeringexcel.com, 2018). The user may want to perform repeated simulations of the same purge to evaluate if the same $\mathrm{K}_{\text {avg }}$ is being obtained for each solution. Calculation of the same $\mathrm{K}_{\text {avg }}$ would suggest a global solution is being obtained by the solver and not a localized solution.

Under certain cases, a solution may not be reached for cases of excessive drawdown (dewatering of the well screen), dewatering of the $\mathrm{M}_{z}$, or in the solution of low hydraulic conductivity values of "tight" formations. Reducing the length of $\mathrm{M}_{\mathrm{z}}$ may assist in achieving a solution in some cases.

\section{Assumptions and Limitations}

There are multiple assumptions and limitations associated with the use of the PAT. The most important limitation is that the PAT assumes steady-state conditions although depletion of well storage is accounted for by adjusting pump rates by the well volume depleted. Users who need simulations of more complex wellbore flow processes should consider the use of numerical models for wellbore flow such as the Multi-Node Well package of MODFLOW (Halford and Hanson, 2002).

Important assumptions of the model include:

1. Confined, steady-state conditions approximate radial flow (Dupuit-Theim equation).

2. The formation adjacent to the well opening is the controlling part of the aquifer contributing water to the well. 


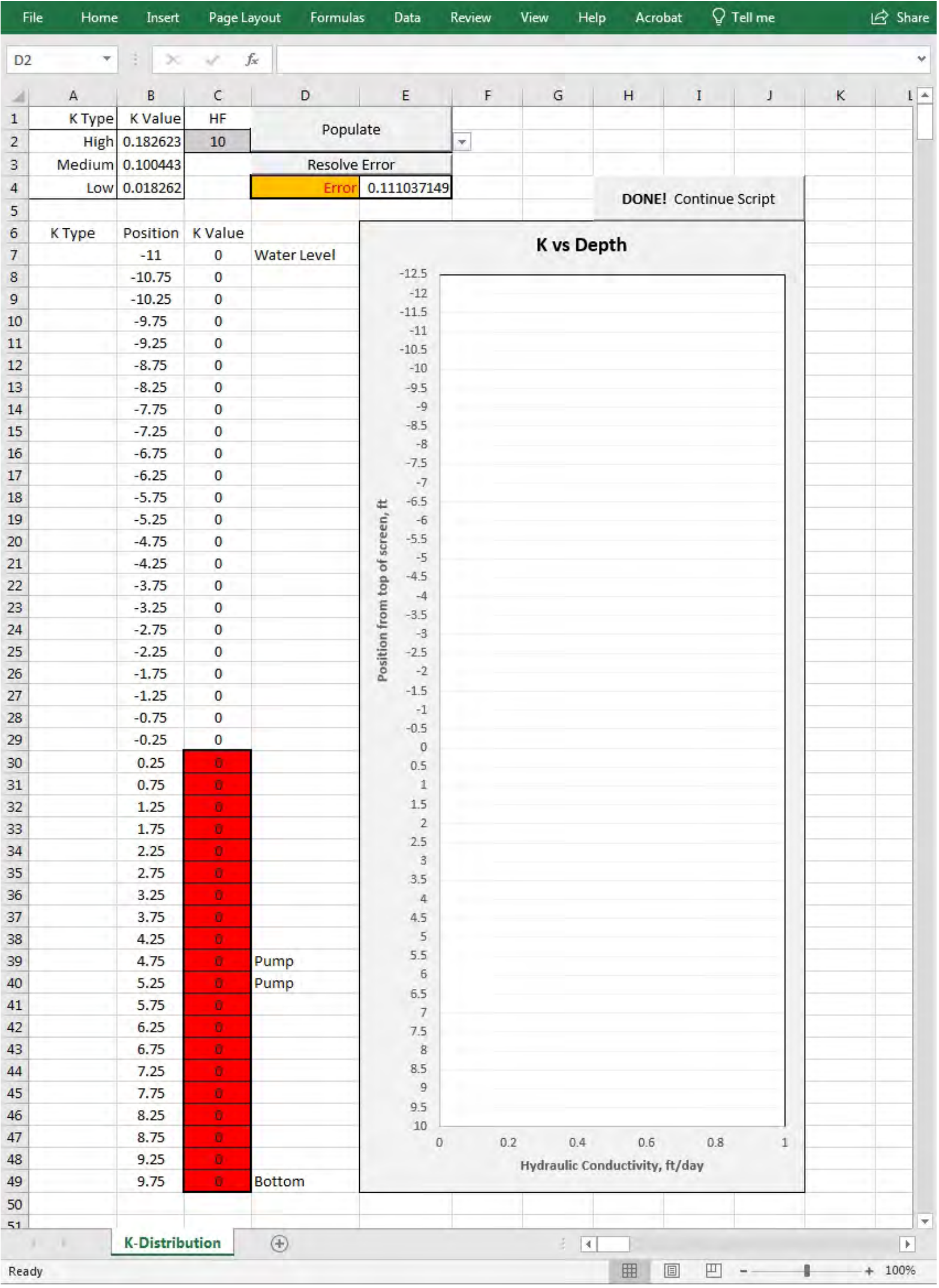

Figure 10. Reproduction of the "K-distribution" worksheet before layer entry for the Purge Analyzer Tool. [HF, heterogeneity factor; $\mathrm{ft}$, feet; $\mathrm{ft} / \mathrm{day}$, feet per day] 


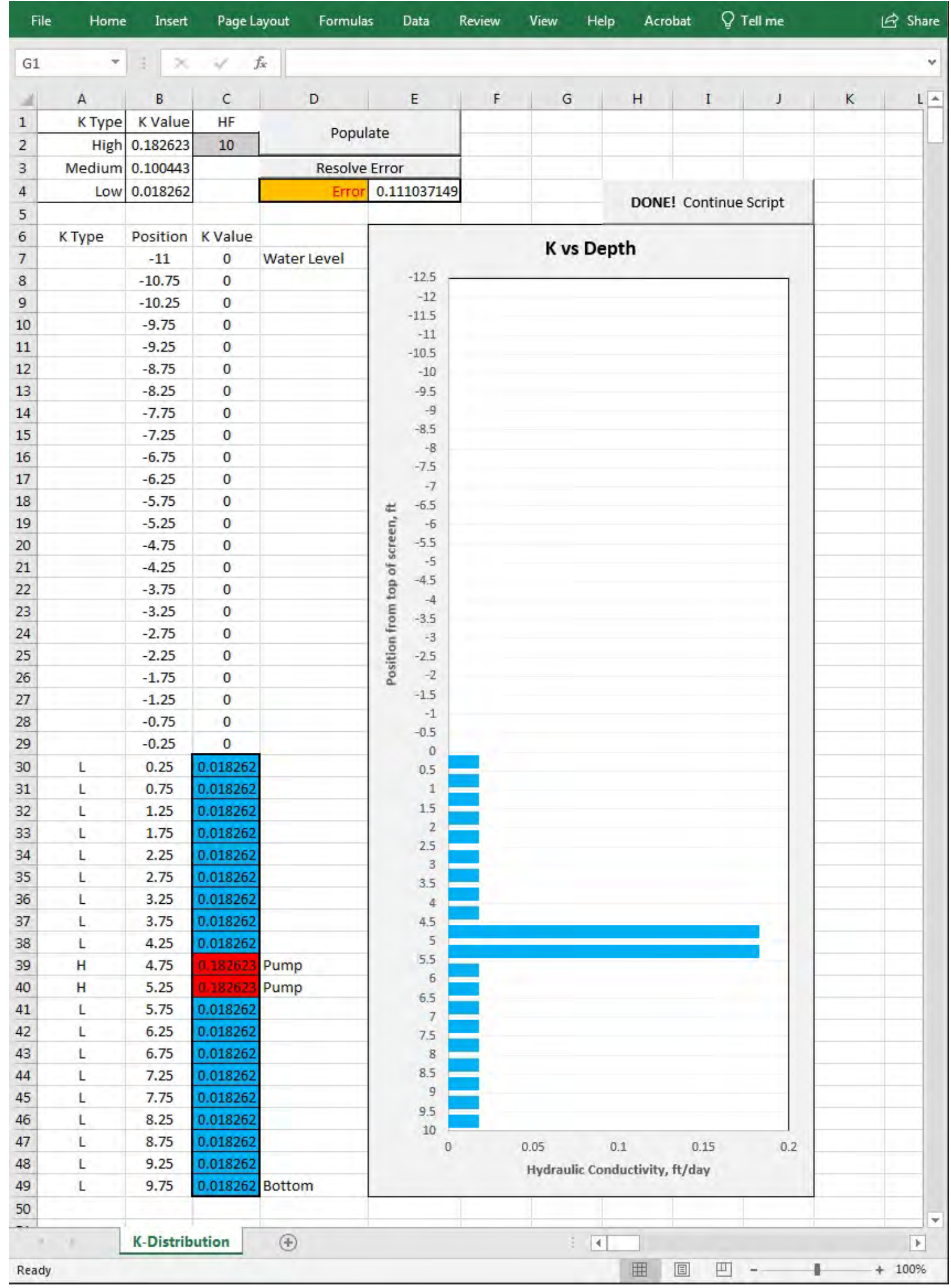

Figure 11. Reproduction of the "K-distribution" worksheet after layer entry using a rock fracture analogy where the fracture exists at the middle of the well opening for the Purge Analyzer Tool. Values are absolute and specified based on relation in equation 3 [HF, heterogeneity factor; $\mathrm{ft}$, feet; $\mathrm{ft} / \mathrm{day}$, feet per day] 
3. Vertical velocity in the well-screened interval is an average velocity calculated by assuming piston flow (no frictional effects).

4. Horizontal flow into the well from the formation is assumed. Users should know that this may not be the case for many shallow monitoring wells or partially penetrating wells that are affected by converging vertical flow.

5. Flow in the well is vertical toward the pump intake outside $\mathrm{M}_{\mathrm{z}}$.

6. Drawdown (s) in the well is uniform over the well opening.

7. $\mathrm{Q}_{\mathrm{v}}$ is calculated by a conservation of mass at each discretized interval.

8. The radius of influence $\left(\mathrm{R}_{\mathrm{o}}\right)$ is set at 10 feet.

9. Storage (S) contributions from outside the well is assumed negligible.

10. The effects of the sand pack on the horizontal or vertical flow is not accounted for.

11. The well screen or well opening is assumed to be unclogged and not a limiting factor in well inflow.

12. Travel time from the $\mathrm{M}_{\mathrm{z}}$ to the pump intake and to the surface via the discharge line is not accounted for but is assumed to be small.

13. In-well flow outside the $\mathrm{M}_{\mathrm{z}}$ is laminar.

14. No ambient flow is present.

15. For the reverse mode, $\mathrm{Q}_{\mathrm{v}}$ contributes to satisfying pump rate $Q_{p}$.

Transient storage effects may be significant in cases where the drawdown (s) takes significant time to stabilize, in which case the analysis will overestimate values of $\mathrm{K}_{\mathrm{avg}}$. The impact of formation $\mathrm{S}$ on $\mathrm{K}_{\text {avg }}$ was evaluated by comparing the calculated $\mathrm{K}_{\mathrm{avg}}$ from the Theis equation, which accounts for aquifer storage, to the calculated $\mathrm{K}_{\text {avg }}$ from the Dupuit-Theim equation as used by this analytical model (Harte, 2017). For a 1-ft drawdown or less, the effect of $\mathrm{S}$ for values of $<0.001$ results in a small error (approximately a factor-of-2 difference) in the $\mathrm{K}_{\text {avg }}$ calculated with this model. As long as the distribution of well inflow remains relatively the same along the screen and $\mathrm{S}$ is uniform, effects on the computation of travel time by the PAT should be relatively small.

Another important limitation is the effect of the $\mathrm{M}_{\mathrm{z}}$ and pump tubing in extending travel time to the surface where samples are retrieved, as the PAT does not account for these. Travel times could be a factor for $\mathrm{M}_{\mathrm{z}}>3 \mathrm{ft}$ and discharge lines $>100 \mathrm{ft}$. In most cases, an $\mathrm{M}_{\mathrm{z}}$ of $1 \mathrm{ft}$ will produce a delay of only a couple of minutes. However, a discharge line of $100 \mathrm{ft}$ could delay travel times to the surface by more than 3 mins.
Therefore, as a rule of thumb, samples should be collected after 10 mins of reaching capture criteria indicated by the PAT.

A sand pack is not simulated in the model. For an open borehole, a sand pack is not applicable because it is not used. However, a sand pack for a well screen can affect the distribution of well inflow particularly if it extends beyond the well screen interval. In this case, it will increase radial flow in the adjacent upper or lower interval of the well screen.

Lastly, well clogging can prevent well inflow from layers that may or may not be productive. Where a sand pack is used, the sand pack will redistribute well inflow to other intervals of the well screen that are not clogged. Therefore, the interval receiving redistributed radial well inflow will have water from another layer and not be indicative of water chemistry from that layer. Simulations with PAT will not be able to replicate the redistributed well inflow.

\section{Applications}

With little information besides well construction, anticipated $\mathrm{P}_{\mathrm{L}}$, and pumping rates, the effect of various levels of heterogeneity can be assessed on in-well flow and time of travel during sampling. Table 1.1 and figure 1.1 illustrate differences between homogeneous and heterogeneous conditions for a hypothesized case of a single fracture in a rock well where the fracture is positioned at different locations (intersections) in the well opening. For the simulations shown, the $\mathrm{P}_{\mathrm{L}}$ is located at $2 \mathrm{ft}$ below the top of the casing and within a $10-\mathrm{ft}$ well opening using the input parameters from figure 2 of this report. The homogeneous case shows a smoother transition of aquifer capture. For the heterogeneous cases that simulate a single fracture 100 times the hydraulic conductivity of the rock matrix (nonfractured part of rock), the distance between the $P_{L}$ and fracture location dominates in-well flow and travel times. A one-order-of-magnitude difference (10 to 100 mins) in arrival time of flow from the fracture, as indicated by the first steep rise on the aquifer fracture graph, occurs when the fracture is located at opposing ends of the well opening (top or bottom of well opening). The tails are a product of the small inflow from the rock matrix, and the spikes represent the large inflow from the fracture. Placing the $\mathrm{P}_{\mathrm{L}}$ in the well casing will exacerbate this difference and increase differences in capture times.

Based on fracture location, an elongated tail may occur between 90 to 100 percent capture or 0 to 10 percent capture depending on the $\mathrm{P}_{\mathrm{L}}$ (appendix 1). When the fracture is located at the bottom of the well opening (appendix 1), the initial percent capture of water is small, increasing slowly until the water contributed by the fracture reaches the pump intake (approximately at $90 \mathrm{~min}$ ) ramping the percent capture to 90 to 100 percent almost immediately; under this case there is no elongated tail at the end. This sequence of percent capture is flipped when the fracture is located at the top of the well opening (appendix 1). Following the start of capture of water 
from the fracture (appendix 1; >10-min mark), an elongated tail ensues between 90-100 percent capture time from the contribution of flow from the rock matrix. For all practical purposes, stabilization of physicochemical characteristics of water quality would likely occur at the 90 percent capture mark. Other application examples are provided in appendixes 2 and 3. In appendix 2, an example showing the application of assigning heterogeneity in the simulation based on a lithologic log is included. In appendix 3 , an example showing the effect of well construction on travel times and aquifer capture is provided.

\section{Summary}

The Purge Analyzer Tool (PAT) can be used to help guide sample considerations (pump location, rate, and time) needed to help collect representative groundwater samples from wells. The criteria used to assess sample representativeness is the time needed to complete flushing of the well opening by allowing sufficient piston transport time for groundwater originating from the well opening to reach the pump intake. Prior to that time, pumped water is a combination of well water in storage and recent inflow from the aquifer. In reality, sample representativeness is a subjective term dependent on study objectives. Therefore, the greatest utility of PAT may be the insight gained into the nature of time-varying capture of purged water and how that may relate to targeted sample volumes. The PAT can be used also to assess the sensitivity of aquifer capture of groundwater sampling networks to factors such as heterogeneity; providing a new variable in the assessment of water chemistry results. Users should be fully aware of the limitations and assumptions incorporated into the PAT including the assumption of steady-state flow although well storage depletion is accounted for by adjusting the pump rate.

Historically, confirmation of sample representativeness for low-flow sampling and volumetric extracted sampling (Barcelona and others, 1994) has depended on stabilization of drawdown and stabilization of physicochemical water quality characteristics such as specific conductance and water temperature. The PAT offers another method to assess capture by coupling arrival time of sample water to the pump intake to the stabilization of physicochemical water quality characteristics. In cases where contemporaneous stabilization and arrival times (as demonstrated in capture graphs) are noted, physicochemical stabilization can be confirmed, thereby avoiding premature sampling based on temporary periods of stabilization. In cases where they are not contemporaneous, the differences in time can be assessed to help evaluate whether further purging may be required given sampling objectives.

\section{References Cited}

Barcelona, M.J., Wehrraann, H.A., and Varljen, M.D., 1994, Reproducible well purging procedures and VOC stabilization criteria for ground water sampling: Ground Water, v. 32, no. 1, p. 12-22, accessed May 5, 2016, at https://doi.org/10.1111/j.1745-6584.1994.tb00605.x.

Engineerexcel.com, 2018, accessed September 30, 2019, at http://www.engineerexcel.com/excel-solver-solvingmethod-choose/)

Halford, K.J., and Hanson, R.T., 2002, User guide for the drawdown-limited, multi-node well (MNW) package for the U.S. Geological Survey's modular three-dimensional ground-water flow model, versions MODFLOW-96 and MODFLOW-2000: U.S. Geological Survey Open-File Report 02-293, 33 p.

Harte, P.T., 2017, In-well time-of-travel approach to evaluate optimal purge duration during low-flow sampling of monitoring wells: Environmental Earth Sciences, v. 76, 13 p., accessed March 21, 2017, at https://doi.org/10.1007/ s12665-017-6561-5.

Lohman, S.W., 1979, Ground-water hydraulics: U.S. Geological Survey Professional Paper 708, 70 p.

Streeter, V.L., and Wylie, E.B., 1985, Fluid Mechanics: Eighth edition, McGraw-Hill Book Co., New York, New York, $586 \mathrm{p}$. 

Appendixes 1-3 


\section{Appendix 1. Solution Examples using Purge Analyzer Tool}

The effect of $P_{L}$ and $M_{z}$ on simulated travel times is presented in this section. Both parameters affect hydraulic controls on flow and time of travel. Also, in this section, the effect of formation heterogeneity on travel times is illustrated for a simple case of a single fracture in competent rock intersecting the well at different depths.

\section{Effect of the mixing zone $\left(M_{z}\right)$}

Table 1.1 summarizes the range of travel times for well and hydraulic conditions noted in figure 1 while adjusting values for two parameters: (1) the placement of the pump intake $\left(\mathrm{P}_{\mathrm{L}}\right)$ and (2) size of the mixing zone $\left(\mathrm{M}_{\mathrm{Z}}\right)$. Capture times are sensitive to both parameters as denoted by the time to achieve 100 percent capture. For example, a pump intake set in the casing $\left(\mathrm{P}_{\mathrm{L}}<0\right)$ will increase travel times by over 8 minutes. Additionally, a larger $\mathrm{M}_{\mathrm{z}}$ will decrease computed travel times by 1.5 minutes because vertical travel is determined up to the boundary of $\mathrm{M}_{\mathrm{z}}$.

\section{Effect of Heterogeneity}

This section includes an example of the effect of fracture position relative to $\mathrm{P}_{\mathrm{L}}$ on travel times and the amount of aquifer fraction captured during pumping. While steady-state flow is assumed for these simulations, transport is transient, and the amount of aquifer capture varies until equilibrium is reached as measured by the arrival time of the most distant intervals of formation water. The shape of the aquifer capture curves provides insight into the proximity of the fracture relative to the $\mathrm{P}_{\mathrm{L}}$ (fig. 1.1).

Table 1.1. Effect of pump location $\left(P_{L}\right)$, mixing zone $\left(M_{z}\right)$, and horizontal flow $\left(Q_{H}\right)$ on travel times. [ft/min, cubic feet per minute; $\mathrm{ft}$, feet]

\begin{tabular}{|c|c|c|c|c|c|c|c|c|c|c|}
\hline $\begin{array}{l}\text { Simulation } \\
\text { number }\end{array}$ & $n \quad \underset{\left(\mathrm{ft}^{3} / \mathrm{min}\right)}{\mathbf{0}_{\mathrm{p}}^{8}}$ & $\begin{array}{c}\mathbf{0}_{\mathrm{p}^{\prime}}{ }^{9} \\
\left(\mathrm{ft}^{3} / \mathrm{min}\right)\end{array}$ & $\begin{array}{c}\mathbf{s}^{1} \\
(\mathrm{ft})\end{array}$ & $\begin{array}{l}L_{s}^{4} \\
(f t)\end{array}$ & $\begin{array}{l}\mathrm{L}_{\mathrm{cw}}{ }^{2} \\
(\mathrm{ft})\end{array}$ & $\begin{array}{l}P_{L}^{6} \\
(f t)\end{array}$ & $\underset{\left(f^{3} / \min \right)}{\mathbf{Q}_{H}{ }^{7}}$ & $\begin{array}{c}1 / 2 M_{z}^{5} \\
(f t)^{5}\end{array}$ & $\begin{array}{l}\mathrm{L}_{\mathrm{T}}^{3} \\
\text { (ft) }\end{array}$ & $\begin{array}{c}\text { 100-percent } \\
\text { capture time } \\
\text { (minutes) }\end{array}$ \\
\hline 1 & 0.0106 & 0.0085 & 10 & 10 & 11 & -3 & 0 & 1.5 & 0.25 & 83.5 \\
\hline 2 & 0.0106 & 0.0085 & 10 & 10 & 11 & -3 & 0 & 0.5 & 0.25 & 85 \\
\hline 3 & 0.0106 & 0.0085 & 10 & 10 & 11 & -1 & 0 & 0.5 & 0.25 & 82 \\
\hline 4 & 0.0106 & 0.0085 & 10 & 10 & 11 & 2 & 0.0008 & 0.5 & 0.25 & 76.5 \\
\hline 5 & 0.0106 & 0.0085 & 10 & 10 & 11 & 5 & 0.0008 & 0.5 & 0.25 & 69 \\
\hline 6 & 0.0106 & 0.0085 & 10 & 10 & 11 & 5 & 0.0017 & 1.5 & 0.25 & 60.5 \\
\hline 7 & 0.0106 & 0.0085 & 10 & 10 & 11 & 8 & 0.0008 & 0.5 & 0.25 & 76.5 \\
\hline \multicolumn{11}{|c|}{$\begin{array}{ll}{ }^{1} \mathrm{~s} & \text { Drawdown }\end{array}$} \\
\hline \multicolumn{11}{|l|}{${ }^{2} \mathrm{~L}_{\mathrm{cw}}$} \\
\hline \multicolumn{11}{|l|}{${ }^{3} \mathrm{~L}_{\mathrm{T}}$} \\
\hline \multicolumn{11}{|c|}{ Lengm or screen or open in } \\
\hline \multicolumn{11}{|l|}{${ }^{5} \mathrm{M}_{\mathrm{z}}$} \\
\hline \multicolumn{11}{|c|}{ Pump locatio } \\
\hline \multicolumn{11}{|c|}{ 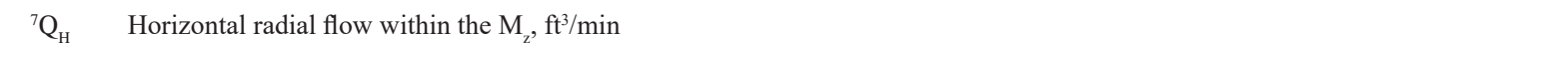 } \\
\hline \multicolumn{11}{|c|}{ Average pumping rate, $\mathrm{L} / \mathrm{m}$} \\
\hline${ }^{9} \mathrm{Q}_{\mathrm{p}}$, & Adjusted avera & pumping & ha & fon & ora & $\mathrm{ft}^{3} / 1$ & & & & \\
\hline
\end{tabular}


A

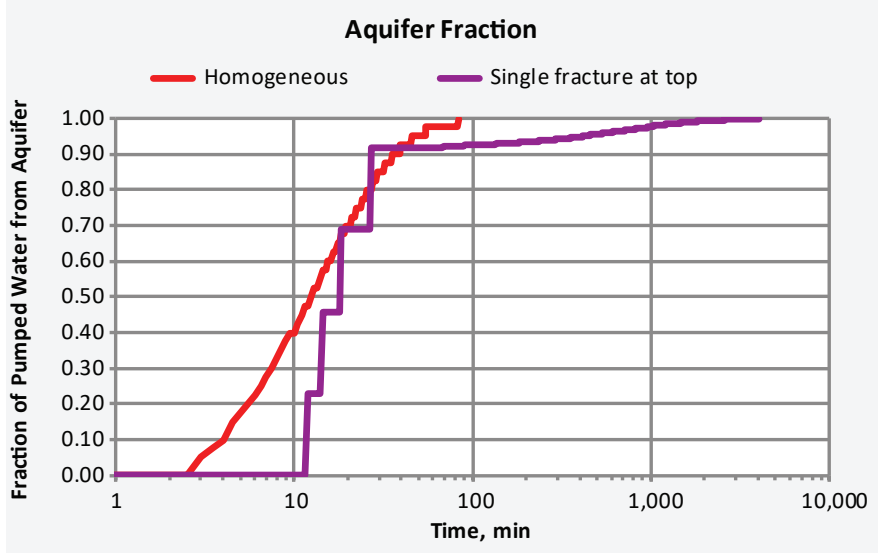

B

Aquifer Fraction

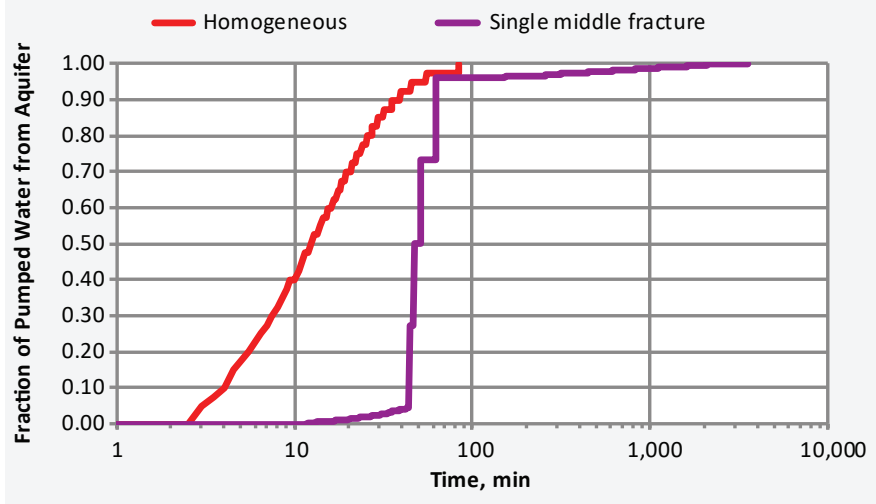

c

Aquifer Fraction

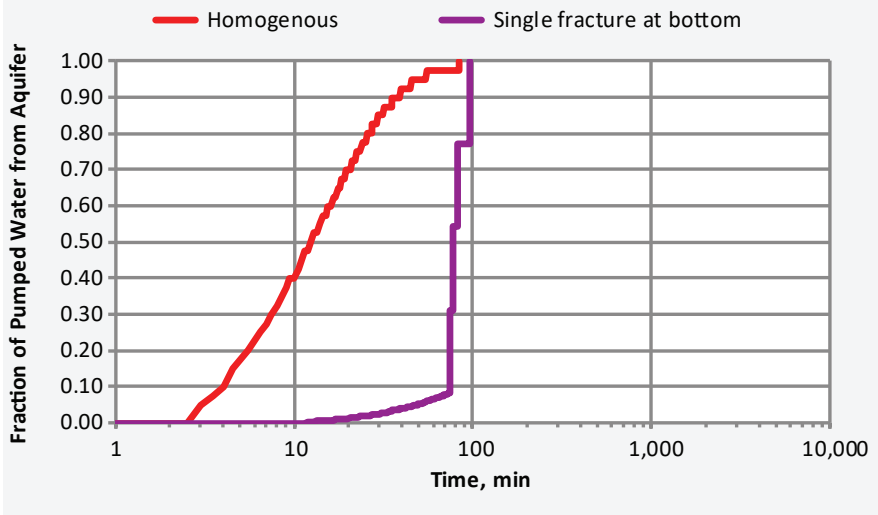

Figure 1.1. Graphs showing effect of heterogeneity on amount of pumped water captured from the aquifer (aquifer fraction capture) for $A$, fracture at top of well opening, $B$, fracture at middle of well opening, and $C$, fracture at bottom of well opening. [min, minutes; Pump position is at 2 feet below the top of the well opening] 


\section{Appendix 2. Incorporation of Stratigraphic Information in Simulation}

While appendix 1 included simulation examples of hypothetical conditions, appendix 2 (and 3) include examples of actual field data from sites. Appendix 2 includes an example of a lithologic log from a monitoring well at the Longhorn Army Ammunition Plant in Karnack, Texas (AECOM Technical Services, Inc., 2015), and the simulated output from a bimodal hydraulic conductivity distribution that was informed by the $\log$ (figs. 2.1 and 2.2). The upper part of the well screen was simulated with a relatively low hydraulic conductivity and the underlying unit was simulated with a high hydraulic conductivity to match the stratigraphic pattern from the log.

\section{References Cited}

AECOM Technical Services, Inc., 2015, Draft Feasibility Study, LHAPP-18/24, Burning Ground no. 3 and Unlined Evaporation Pond, Longhorn Ammunition Plant, Karnack, Texas: Prepared for the U.S. Army Corp of Engineers, Tulsa District, contract no. W912DY-09-D-0059 Task Order No. DS01, 1133 p. 


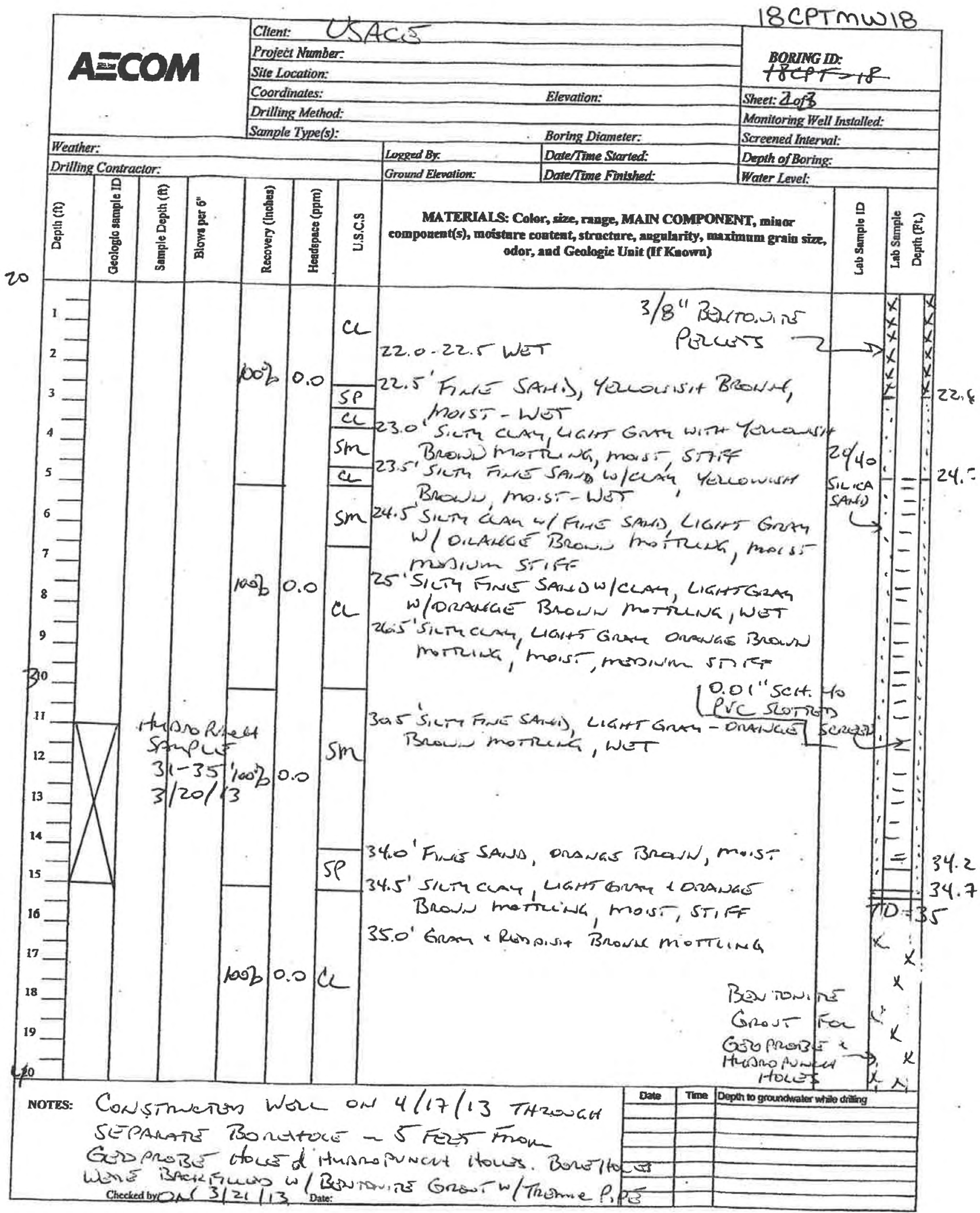

Figure 2.1. Lithologic log from monitoring well 18CPTMW18, a 1.5-inch diameter well with a 10-(foot; $\mathrm{ft}$ ) screen, located at an ammunition site in Texas that shows a predominantly clayey unit from 24.2 to $30.5 \mathrm{ft}$ depth below land surface and a slightly coarser underlying silty sand from 30.5 to $34.2 \mathrm{ft}$ below land surface. [ft, feet; CL, clay; SP, fine sand; SM, silty sand with clay; TD, total depth] 
A

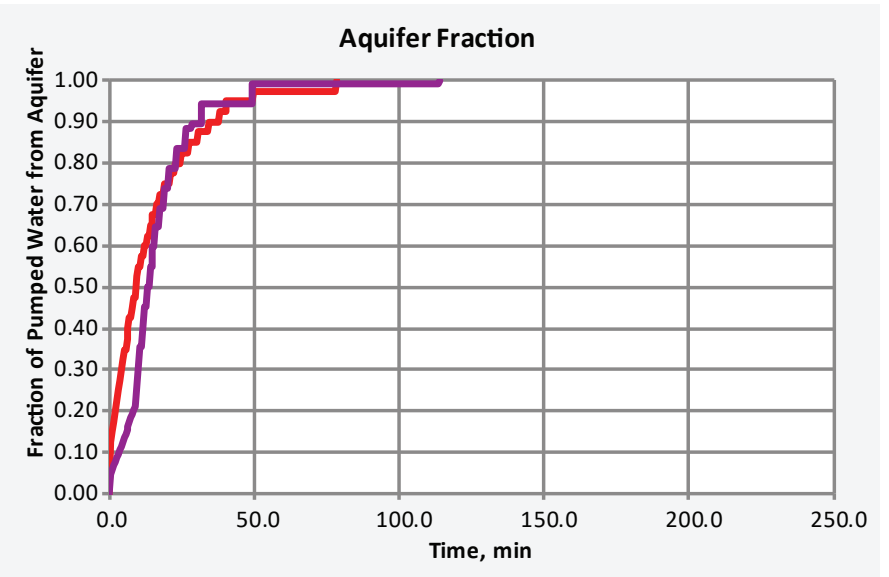

$\boldsymbol{B}$

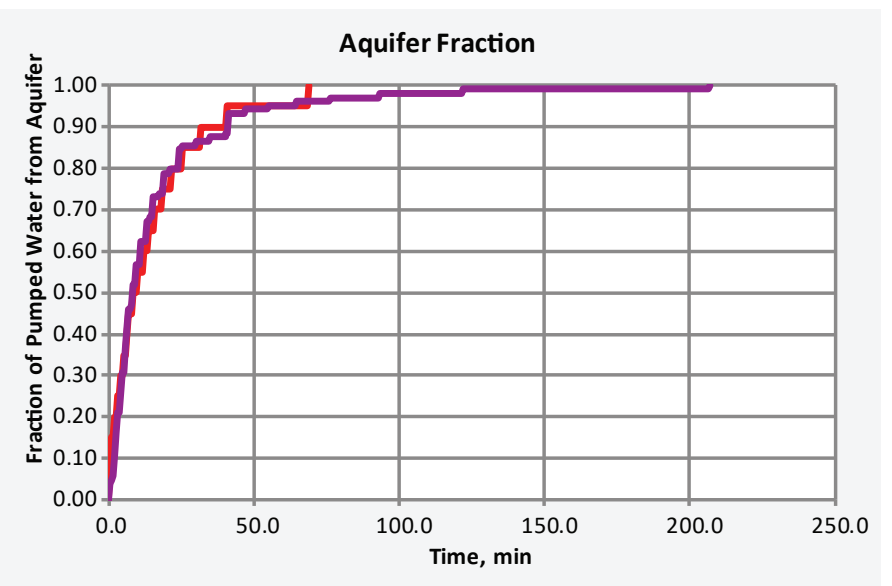

c

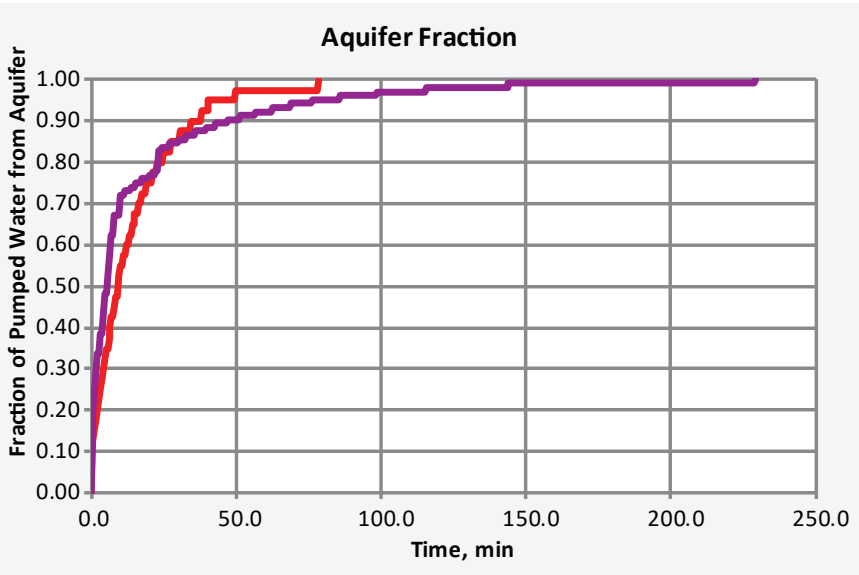

EXPLANATION

Homogeneous Heterogenous

Figure 2.2. Aquifer fraction captured while pumping for monitoring well 18CPTMW18 with a simulated bimodal hydraulic conductivity distribution at a factor of 5 between low (top of screen) and high (bottom of screen) $\mathrm{K}_{\text {Layer }}$ where pump position was placed at $A, 1$ foot below top of opening, $B, 5$ feet below top of opening, and $C$, 9 -ft below top of opening. [ $\mathrm{K}_{\text {Layer }}$, hydraulic conductivity of modeled layers; min, minutes] 


\section{Appendix 3. Additional Examples of Input and Output}

Appendix 3 includes input and output example of a homogeneous condition for two monitoring wells located in New Mexico near the Homestake Superfund site (Harte and others, 2019). Whereas the formation at both wells have similar $\mathrm{K}_{\text {avg }}$, the differences in well diameter and length of screen affects capture times (figs. 3.1 and 3.2). The time to achieve 90 percent aquifer capture is much quicker for well ND (fig. 3.1) than for well DD2 (fig. 3.2) because of the longer screen interval for well DD2.

\section{References Cited}

Harte, P.T., Blake, J.M., Thomas, J.V., and Becher, K.D., 2019, Identifying natural and anthropogenic variability of uranium at the well scale, Homestake Superfund site, near Milan, New Mexico, USA: Environmental Earth Science, v. 78, p. 95, https://doi.org/10.1007/s12665-019-8049-y. 
A

\begin{tabular}{|c|c|c|}
\hline \multicolumn{2}{|l|}{ Initial Inputs \& Calculations } & \\
\hline Input Parameters & Inputs & \\
\hline Well Name & ND & \\
\hline Date (mm/dd/yyy) & $10 / 6 / 2016$ & Units \\
\hline Depth to Water below reference, DTW & 38.93 & $\mathrm{ft}$ \\
\hline Depth to Top of Screen below reference, DTS & 52 & $\mathrm{ft}$ \\
\hline Length of Screen, $L_{s}$ & 20 & $\mathrm{ft}$ \\
\hline Well Diameter, $\mathbf{D}_{\text {well }}$ & 4 & inches \\
\hline Actual or Anticipated purging time, $t_{\text {purge }}$ & 65 & $\min$ \\
\hline Averaged Purge Rate, $Q_{p}$ & 6.064 & $L / \min$ \\
\hline Drawdown, $\mathbf{s}$ & 1.72 & $\mathrm{ft}$ \\
\hline Heterogeneity Factor, HF (1=Homogeneous) & 1.00 & $\begin{array}{l}\text { Dimensi } \\
\text { onless }\end{array}$ \\
\hline Hydraulic Conductivity, $\mathrm{K}_{\mathrm{avg}}$ & 5.7785 & $\mathrm{ft} / \mathrm{day}$ \\
\hline
\end{tabular}

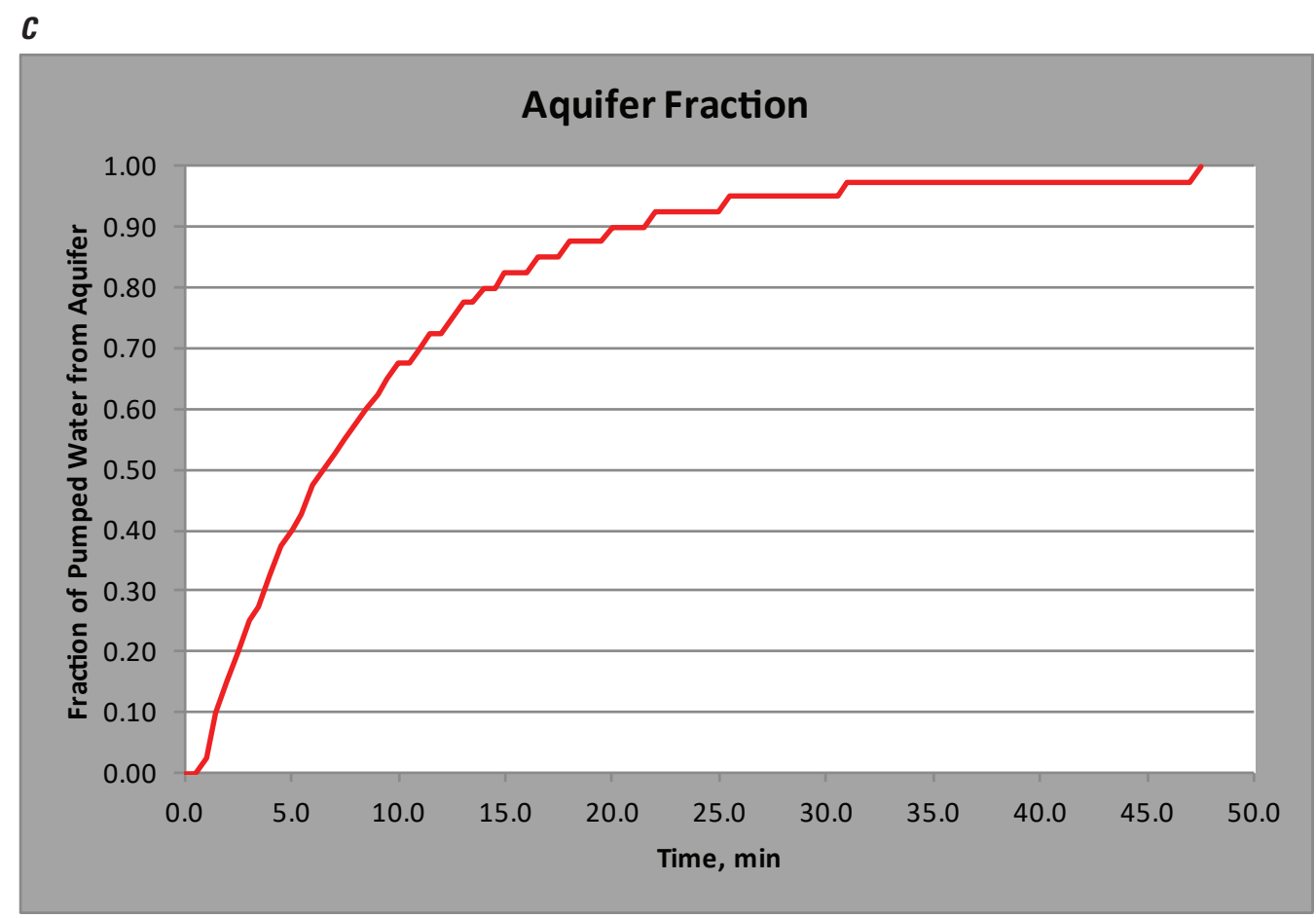

Figure 3.1. Reproduction of $A$, input parameters, $B$, model simulation parameters, and $C$, aquifer fraction captured while pumping for monitoring well ND in New Mexico under homogeneous conditions. [90 percent capture is at 21 minutes; $\mathrm{ft}$, feet; min, minutes; L/min, liters per minute] 
$\boldsymbol{A}$

\begin{tabular}{|c|c|c|}
\hline \multicolumn{2}{|l|}{ Initial Inputs \& Calculations } & \\
\hline Input Parameters & Inputs & \\
\hline Well Name & DD2 & \\
\hline Date (mm/dd/yyyy) & $10 / 7 / 2016$ & Units \\
\hline Depth to Water below reference, DTW & 45.26 & $\mathrm{ft}$ \\
\hline Depth to Top of Screen below reference, DTS & 50 & $\mathrm{ft}$ \\
\hline Length of Screen, $L_{s}$ & 40 & $\mathrm{ft}$ \\
\hline Well Diameter, $\mathbf{D}_{\text {well }}$ & 5 & inches \\
\hline Actual or Anticipated purging time, $\mathbf{t}_{\text {purge }}$ & 138 & $\min$ \\
\hline Averaged Purge Rate, $Q_{p}$ & 6.06 & $L / \min$ \\
\hline Drawdown, s & 0.91 & $\mathrm{ft}$ \\
\hline Heterogeneity Factor, HF (1=Homogeneous) & 1.00 & $\begin{array}{l}\text { Dimensi } \\
\text { onless }\end{array}$ \\
\hline Hydraulic Conductivity, $\mathrm{K}_{\text {avg }}$ & 5.1943 & $\mathrm{ft} /$ day \\
\hline
\end{tabular}

$B$

\begin{tabular}{|l|r|l|}
\hline \multicolumn{1}{|c|}{ Program Variables } & Inputs & Units \\
\hline $\begin{array}{l}\text { Pump Location relative to top of screen (Above } \\
\text { screen specify negative number for absolute } \\
\text { distance), } \mathbf{P}_{\mathbf{L}}\end{array}$ & -2 & $\mathrm{ft}$ \\
$\begin{array}{l}1 / 2 \text { Mixing Zone Buffer length above/below pump } \\
\text { intake, } 1 / 2 \mathbf{M}_{\mathbf{z}}\end{array}$ & 0.5 & $\mathrm{ft}$ \\
$\begin{array}{l}\text { Cell Thickness of layers to compute horizontal radial } \\
\text { flow, } \mathbf{L}_{T}\end{array}$ & 0.5 & $\mathrm{ft}$ \\
$\begin{array}{l}\text { Time interval (dt) for computation of flow and } \\
\text { Aquifer Fraction graph }\end{array}$ & 0.5 & $\mathrm{~min}$ \\
\hline
\end{tabular}

\section{C}

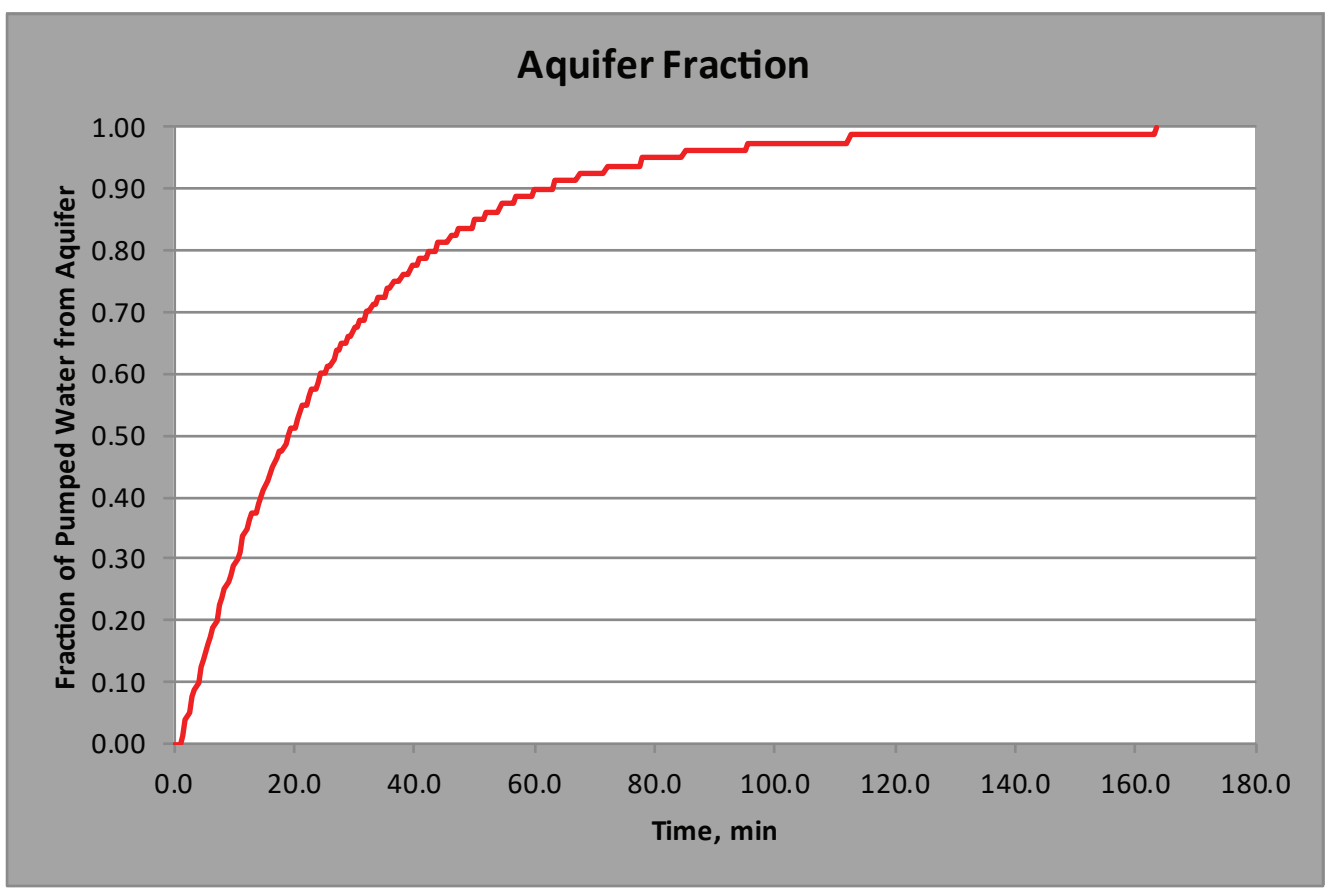

Figure 3.2. Reproduction of $A$, input parameters, $B$, model simulation parameters, and $C$, aquifer fraction captured while pumping for monitoring well DD2 in New Mexico under homogeneous conditions. [90 percent capture is at 63 minutes; feet; min, minutes; L/min, liters per minute] 

For more information about this report, contact: Director, New England Water Science Center U.S. Geological Survey

331 Commerce Way, Suite 2

Pembroke, NH 03275

dc_nweng@usgs.gov

or visit our website at

https://www.usgs.gov/centers/new-england-water

Publishing support provided by the

Pembroke Publishing Service Center 
I

气े

辛

疋 